University of Nebraska - Lincoln

DigitalCommons@University of Nebraska - Lincoln

USDA Forest Service / UNL Faculty Publications U.S. Department of Agriculture: Forest Service --

National Agroforestry Center

2011

\title{
A simulation of probabilistic wildfire risk components for the continental United States
}

\author{
Mark A. Finney \\ USDA Forest Service, mfinney@fs.fed.us \\ Charles W. McHugh \\ USDA Forest Service \\ Isaac C. Grenfell \\ USDA Forest Service \\ Karin L. Riley \\ Systems for Environmental Management \\ Karen C. Short \\ USDA Forest Service
}

Follow this and additional works at: https://digitalcommons.unl.edu/usdafsfacpub

Finney, Mark A.; McHugh, Charles W.; Grenfell, Isaac C.; Riley, Karin L.; and Short, Karen C., "A simulation of probabilistic wildfire risk components for the continental United States" (2011). USDA Forest Service / UNL Faculty Publications. 249.

https://digitalcommons.unl.edu/usdafsfacpub/249

This Article is brought to you for free and open access by the U.S. Department of Agriculture: Forest Service -National Agroforestry Center at DigitalCommons@University of Nebraska - Lincoln. It has been accepted for inclusion in USDA Forest Service / UNL Faculty Publications by an authorized administrator of DigitalCommons@University of Nebraska - Lincoln. 


\title{
A simulation of probabilistic wildfire risk components for the continental United States
}

\author{
Mark A. Finney $\cdot$ Charles W. McHugh • \\ Isaac C. Grenfell · Karin L. Riley · Karen C. Short
}

Published online: 27 March 2011

(C) U.S Governement 2011

This article is a U.S. government work, and is not subject to copyright in the United States.

\begin{abstract}
This simulation research was conducted in order to develop a large-fire risk assessment system for the contiguous land area of the United States. The modeling system was applied to each of 134 Fire Planning Units (FPUs) to estimate burn probabilities and fire size distributions. To obtain stable estimates of these quantities, fire ignition and growth was simulated for 10,000 to 50,000 "years" of artificial weather. The fire growth simulations, when run repeatedly with different weather and ignition locations, produce burn probabilities and fire behavior distributions at each landscape location (e.g., number of times a "cell" burns at a given intensity divided by the total years). The artificial weather was generated for each land unit using (1) a fire danger rating index known as the Energy Release Component (ERC) which is a proxy for fuel moisture contents, (2) a time-series analysis of ERC to represent daily and seasonal variability, and (3) distributions of wind speed and direction from weather records. Large fire occurrence was stochastically modeled based on historical relationships to ERC. The simulations also required spatial data on fuel structure and topography which were acquired from the LANDFIRE project (http://www.landfire.gov). Fire suppression effects were represented by a statistical model that yields a probability of fire containment based on independent predictors of fire growth rates and fuel type. The simulated burn probabilities were comparable to observed patterns across the U.S.
\end{abstract}

\footnotetext{
M. A. Finney $(\bowtie) \cdot$ C. W. McHugh · I. C. Grenfell .

K. C. Short

USDA Forest Service, Missoula Fire Sciences Laboratory, 5775 Highway 10 West, Missoula, MT 59808, USA e-mail: mfinney@fs.fed.us
}

K. L. Riley

Systems for Environmental Management, PO Box 8868, Missoula, MT 59802, USA over the range of four orders of magnitude, generally falling within a factor of 3 or 4 of historical estimates. Close agreement between simulated and historical fire size distributions suggest that fire sizes are determined by the joint distributions of spatial opportunities for fire growth (dependent on fuels and ignition location) and the temporal opportunities produced by conducive weather sequences. The research demonstrates a practical approach to using fire simulations at very broad scales for purposes of operational planning and perhaps ecological research.

\section{Introduction}

For the U.S. Federal land management agencies, a nationalscale assessment of wildfire risk offers a consistent means of understanding and comparing threats to valued resources and predicting and prioritizing investments in management activities that mitigate those risks. An actuarial approach to risk is well suited to strategic planning in fire and land management because it integrates fire probabilities with the consequences (Brillinger 2003; Calkin et al. 2010; Fairbrother and Turnley 2005; Scott 2006). Such quantitative risk assessments are still relatively new to wildland fire, however, in part because of difficulty associated with reliably estimating burn probabilities and variability in fire behavior (Finney 2005). Other challenges involve the estimation of economic or ecological impacts (positive or negative) produced by the physical fire behaviors (Brillinger 2003; Calkin et al. 2010; Kerns and Ager 2007). In this article, we describe the structure of a simulation system designed to estimate the probabilistic components of wildfire risk for Fire Planning Units (FPUs) across the continental U.S. and then evaluate its performance against historical records. A companion article in this issue is 
devoted to the valuation and impact portions of fire risk assessment (see Thompson et al. 2011).

Burn probabilities are the outcome of ignitions and spatial and temporal processes that promote or restrict fire spread across landscapes. Burn probability and associated fire behavior is heavily influenced by large fires because they account for most of the burned area (Podur et al. 2009; Strauss et al. 1989). The term large is used here to refer in a general way to fires that escape initial attack, irrespective of their actual size. Fire size criteria are often used for statistical purposes, however. For example, between 1970 through 2002, fewer than $3 \%$ of fires on Forest Service lands were larger than 121 ha (300 acres) (Calkin et al. 2005). Suppression efforts have presumably been responsible for reducing estimated burning rates and probabilities in the past century (Littell et al. 2009) compared to previous centuries (Stephens et al. 2007). Some of the observed variability in burn probability across the country is related to vegetation and human activities as well as climate (Parisien and Moritz 2009; Schmidt et al. 2002; Schroeder and Buck 1970). The rarity of large fires, in combination with the weather, fuels, topography, and suppression actions unique to each fire, contributes to difficulty in planning and risk modeling and in obtaining the large sample sizes necessary to capture the variability in these events.

Impacts of large fires derive from fire spread across heterogeneous landscapes far from their ignition sources under highly variable weather. Simulations are routinely used for capturing this variability when modeling growth and behavior of individual fires (Anderson et al. 1982; Finney 1998; Richards 1995). Yet, methods for realistically incorporating the variability of ignitions, climate, and specific fire weather patterns in simulations of burn probability are still emerging (Ager et al. 2007, 2010; Beverly et al. 2009; Moritz et al. 2005; Parisien et al. 2005; Parisien and Moritz 2009; Braun et al. 2010). Other methods for addressing large fires in fire management systems and risk assessments have included expert gaming (Bratten et al. 1981), non-spatial stochastic methods (Alvarado et al. 1998; Brillinger 2003), and statistical modeling of historical data (Brillinger et al. 2006; Preisler et al. 2004; Preisler and Westerling 2007).

Despite the difficulties of using spatial simulations for quantitative fire risk assessment, their strength lies in accounting for the variability in physical fire behaviors and the associated consequences that arise because of topology in fire spread. The complex topology of fuel patterns, weather sequences, and fire spread, have strong influences on the patch structure of fire effects (Collins et al. 2007; Wimberly et al. 2009) and the effects of fuel treatments (Finney et al. 2005; King et al. 2008; Schmidt et al. 2008). In fact, the ability to capture fuel treatment effects on local and landscape burn probabilities (see Ager et al. 2007, 2010; Beverly et al. 2009; Parisien et al. 2007; Parisien and
Moritz 2009; Suffling et al. 2008) is a primary motivation of research into use of simulation for risk estimation.

Fireline intensity (energy release per unit length of flame front) is a principal driver of many important fire effects and varies greatly between fires and portions of fires. Fireline intensity (sensu Alexander 1982; Byram 1959) is closely related to impacts on ecological attributes such as tree mortality (Hood et al. 2007; Peterson and Ryan 1986) as well as the controllability of fire (Andrews and Rothermel 1982). Intensity depends not only on local conditions at the time the fire occurs (e.g., fuels, wind speed, moisture content), but also varies greatly with the orientation of the fire front relative to the maximum or heading direction (Catchpole et al. 1982). Thus, the intensity experienced at a particular point on a complex landscape is dependent on relative location of ignitions (Kerby et al. 2007; Parisien and Moritz 2009) and the fire environment up to arrival time. The fireline intensity distribution at a particular point, even under homogenous environmental conditions would, thus, display substantial variability (Catchpole et al. 1992). The simulation system developed here attempts to account for spatial and temporal variation in weather, ignitions, and fuels, and generates burn probability distributions by intensity to permit evaluation of intensity-dependent effects.

\section{Methods}

The large-fire simulation system, referred to here as FSim, consists of modules for weather generation, and for modeling of fire occurrence, fire growth, and fire suppression. The system is designed to simulate the occurrence and growth of fires for thousands of years in order to estimate average burn probabilities and fire size distributions. It was applied independently to each of 134 Fire Planning Units (FPUs) throughout the U.S. and the results compared to historical data from those areas. Each module of this system is described in the following sections.

\subsection{Weather (daily, seasonal, and spatial variation)}

A practical method was required for obtaining a large sample of annual weather data which related to the unique climatic and seasonal patterns of fire occurrence. Given the rarity of large fires in our modern record, thousands of years of daily weather scenarios would be required for simulations to produce moderately stable and repeatable estimates of burn probability. Average burn probability can be estimated for each FPU as the total area burned divided by the total area and number of years, or for each cell as the number of times burned divided by the number of years. Measured weather data are available from the numerous catalogued National Fire Danger Rating System (NFDRS) Remote Automated 
Fig. 1 Map of Fire Planning Units (FPUs) and Geographic Areas (GAs) in the continental U.S.

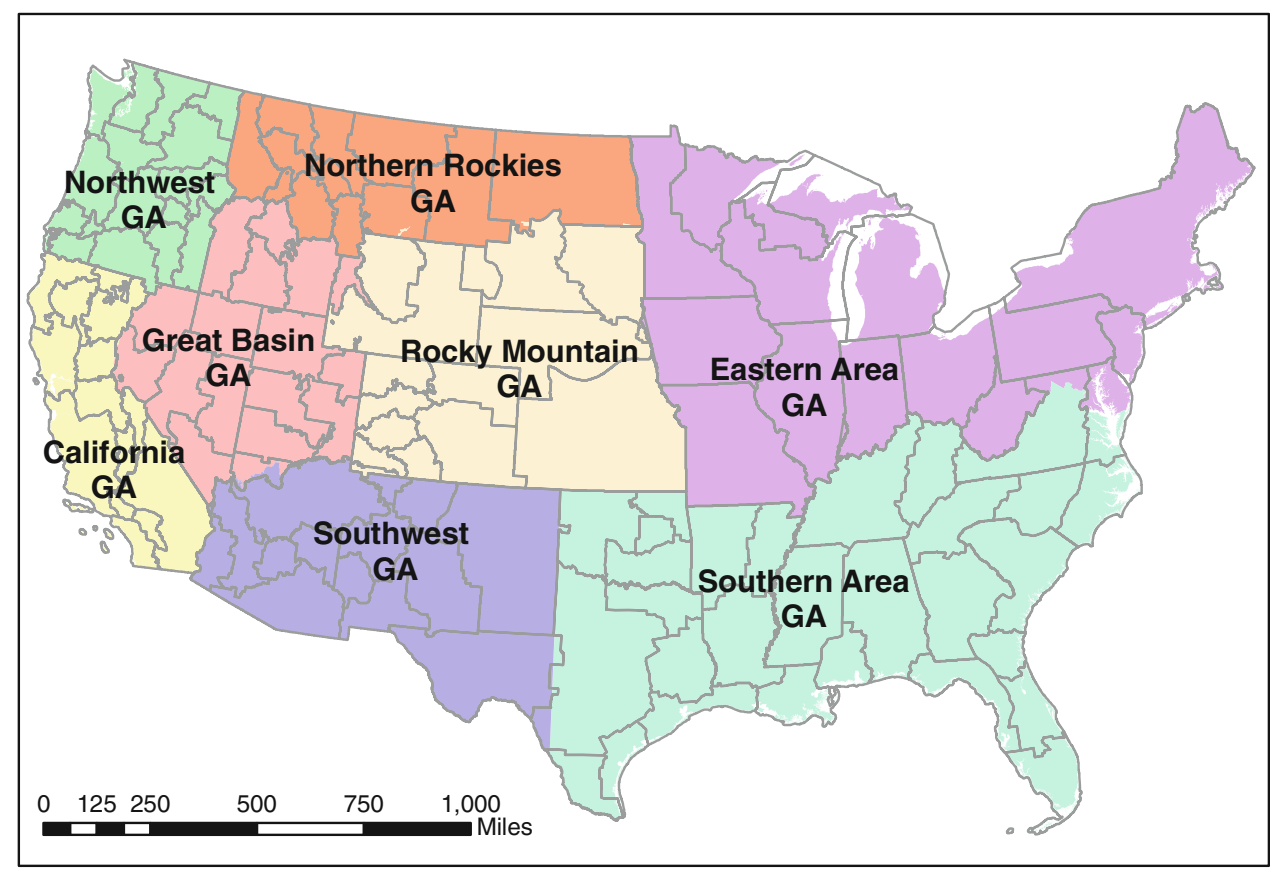

Weather Stations (RAWS) located throughout the U.S. (Zachariasson et al. 2003; http://www.fs.fed.us/raws). These data typically cover the past one to three decades, which is coincident with the most recent set of historical fire records and contemporary fire management policies.

A single representative weather station was chosen within each of 134 Fire Planning Units (FPUs) in the continental U.S. (Fig. 1). The requisite weather and environmental variables needed for fire behavior calculations (Rothermel 1972) consist of a suite of fuel moistures (percentage of dry weight) for six fuel categories and wind speed and direction. Moisture content of dead fuels must be calculated from daily weather records (temperature, humidity, solar radiation, precipitation) for four fuel timelag classes $(1,10,100,1000 \mathrm{~h})$ and for live woody and live herbaceous components (Fosberg and Deeming 1971; Deeming et al. 1977, Andrews 1986, Bradshaw et al. 1984). We relied on a simple method of accounting for the daily and seasonal variability of these separate moisture contents by combining them based on their collective influence on the fire danger rating index Energy Release Component (ERC) of the U.S. National Fire Danger Rating System (NFDRS). The ERC index represents the amount of energy released during flaming spread $\left(\mathrm{BTU} \mathrm{ft} \mathrm{ft}^{-2}\left(\mathrm{~J} \mathrm{~m}^{-2}\right)\right.$ ), and varies only by fuel moisture for a given fuel type. For each FPU, we used NFDRS fuel model "G" because it contains parameters for all fuel components and size classes $(1,10,100,1000 \mathrm{~h}$, live herbaceous, and live woody) (Bradshaw et al. 1984). ERC(G) is, thus, capable of reflecting the influence of both short and long term variations in fuel moisture caused by precipitation and changes

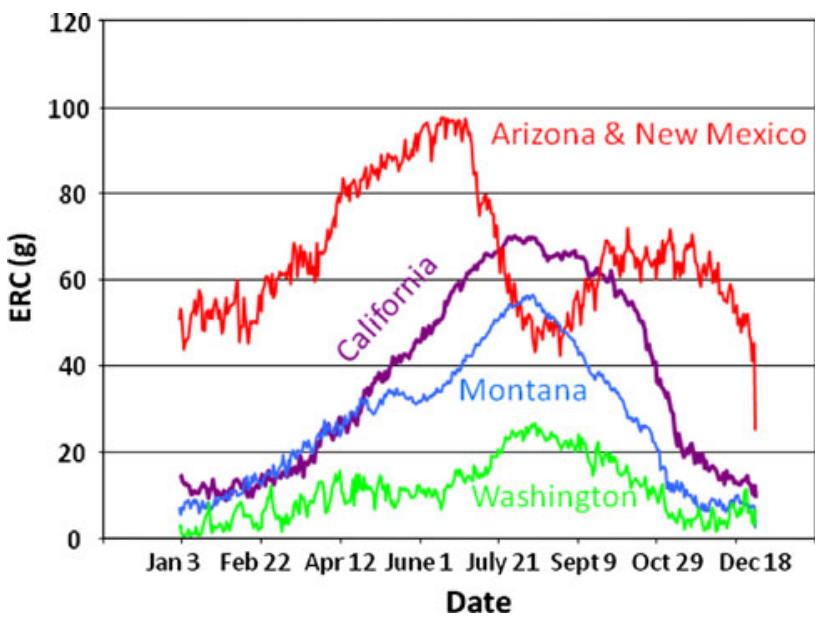

Fig. 2 The average daily value of Energy Release Component index from the U.S. National Fire Danger Rating System is shown for weather stations in four fire climate regions of the western U.S. ERC captures the different trends in amplitude, duration, and timing of seasonal dead and live fuel moisture trends and was thus used as a proxy for fuel moisture in the simulation system

in temperature and humidity. It has shown strong correspondence with fire occurrence in many different climate zones of the U.S. (Andrews et al. 2003) By using $\operatorname{ERC}(G)$ for all FPUs, it becomes a proxy for the influence of fuel moisture on fire behavior and can reflect daily, seasonal, and regional variability for different fire climates of the U.S. (Fig. 2).

The seasonal and annual variability in live and dead fuel moisture (through $\operatorname{ERC}(G)$ ) was modeled using time-series analysis. Time series captures (1) the trend in 
$\operatorname{ERC}(\mathrm{G})$ throughout the year, averaged daily over the period of record, (2) the daily standard deviations, and (3) the average temporal autocorrelation of the $\operatorname{ERC}(G)$ values. $\operatorname{ERC}(\mathrm{G})$ has strong autocorrelation because of the time-lag of larger woody fuel components $(100$ and $1000 \mathrm{~h}$ time lag) which characterizes the time-periods required to asymptotically approach equilibrium in fuel moisture provided steady conditions (Fosberg and Deeming 1971). These three time-series components were then used to generate thousands of hypothetical years of daily $\operatorname{ERC}(G)$ trends for each FPU independently as input to the fire growth modeling.

The time-series modeling is based on a sample of daily values of $\operatorname{ERC}(\mathrm{G})$ (designated as $z(t)$ where $t$ represents days) from a number of years of historical data (e.g., 10 to 20 years). This analysis assumes that:

1. There exists an overall seasonal trend $f(t)$ which remains the same from year to year, which we estimate with a weighted least squares polynomial model of $z(t)$. The weights were the inverse of the daily standard deviations.

2. Daily standard deviations are estimated assuming $z(t)$ are normally distributed around the daily means $\mu(t)$. Visual inspection of $z(t)$ for the FPUs revealed symmetric distributions without heavy tails, thus supported this assumption.

3. The residuals $(z(t)-f(t))$ are autocorrelated in time out to a maximum value of $t^{*}$, and follow some autocorrelation function $\rho(k)$ where $k$ is the lag in days.

The autocorrelation function $\rho(k)$ is used to obtain coefficients $\phi$ (for use later in an autoregressive function) as follows:

$\phi=\boldsymbol{P}_{t *}^{-1} \rho_{t *}$

where

$\boldsymbol{\phi}=\left[\phi_{1}, \phi_{2}, \ldots, \phi_{t^{*}}\right]$

$\rho_{t *}=\left[\rho_{1}, \rho_{2}, \ldots, \rho_{t *}\right]$

and the matrix

$\boldsymbol{P}=\left[\begin{array}{ccccc}1 & \rho_{1} & \rho_{2} & \ldots & \rho_{t *-1} \\ \rho_{1} & 1 & \rho_{1} & \ldots & \rho_{t *-2} \\ \ldots & \ldots & \ldots & \ldots & \ldots \\ \rho_{t *-1} & \rho_{t *-2} & \rho_{t *-3} & \ldots & 1\end{array}\right]$

The overall model for estimating autocorrelated time series values of $\operatorname{ERC}(G)$ is then:

$$
\begin{aligned}
z h a t(t)= & f(t)+\phi_{1}(a(t-1))+\phi_{2}(a(t-2))+\cdots \\
& +\phi_{t *}(a(t-t *))+a(t)
\end{aligned}
$$

In this expression, $a(t)$ is a white noise process with zero mean and a variance obtained from Box and Jenkins (1976, p. 56) which accounts for the variance explained by the autoregressive model:

$\sigma^{2}(t)=\operatorname{var}(a(t)) /\left(1-\rho_{1} \phi_{1}-\rho_{2} \phi_{2} \cdots-\rho_{t *} \phi_{t *}\right)$

For purpose of simulating artificial time series $\operatorname{ERC}(G)$ values, we then simulate a stream of artificial $a(t)^{\prime} s$ with

$\operatorname{var}(\widehat{a(t)})=s^{2}(t) \times\left(1-\rho_{1} \varphi_{1}-\rho_{2} \varphi_{2} \cdots-\rho_{t *} \varphi_{t *}\right)$

We then apply the filter $\phi$ and add the seasonal trend as in Eq. 2. This allows the generation of daily values of $\operatorname{ERC}(\mathrm{G})$ for as many seasons as needed to capture the variability in moisture conditions (Fig. 3a).

The daily $\operatorname{ERC}(G)$ values produced by the time series modeling for an FPU were translated into values of fuel moisture content from a look-up table. A look-up table was constructed for each weather station (each FPU) and contains the average historical fuel moisture contents for each $\operatorname{ERC}(G)$ percentile range. Because this simulation system was intended to simulate only large fires, $\operatorname{ERC}(G)$ categories were fixed at the 80th, 90th and 97th percentiles based on all days in the year. Fire spread was not simulated for days when ERC(G)dropped below the 80th percentile. Daily fire spread calculations also required determination of the length of time for which these moistures apply during the typical afternoon "burning period" which is the portion of each day where fires are most active. Fuel moisture is one of the main weathercaused factors delimiting this period of active fire spread (Chandler et al. 1963; Beverly and Wotton 2007, Fernandes et al. 2008; Leonard 2009). Typically the burning period increases in length as fuels become drier (i.e., fires burn longer with lower fuel moisture). The actual lengths of these afternoon periods is uncertain, but for the purposes of simulation, they were fixed at 1,3 , and $5 \mathrm{~h}$ for the 80th, 90th, and 97th percentile ERC conditions, respectively.

Wind variability was characterized as joint probability distributions of speed and direction during the afternoon hours for each month of the year (Fig. 3b). Each of the monthly distributions of wind speed and direction was sampled at random to produce a 365-day record of these attributes. This approach assumes that wind probabilities, considered jointly, are random from day to day within a given month and uncorrelated with fuel moisture. Wind direction may be weakly autocorrelated beyond one day, however (Kalvova and Sobisek 1981).

Each artificial "year" of weather ultimately generated for fire simulation, therefore, comprised 365 daily values of $\operatorname{ERC}(\mathrm{G})$, wind speed, and wind direction, plus the fuel moisture values indicated by the $\operatorname{ERC}(\mathrm{G})$ time series. Tens of thousands of years of weather scenarios were then generated by this method. 
Fig. 3 Examples of weather data supplied to the simulation for creating artificial daily fire weather, a three years of daily Energy Release Component values (shown in red, blue, and purple) relative to the trend (shown in navy) illustrate the daily and annual variability in this danger rating index that reflects fuel moisture, b joint probability distributions of wind speed and direction displayed as a wind-rose for example months (April, June, August, October) for a selected weather station
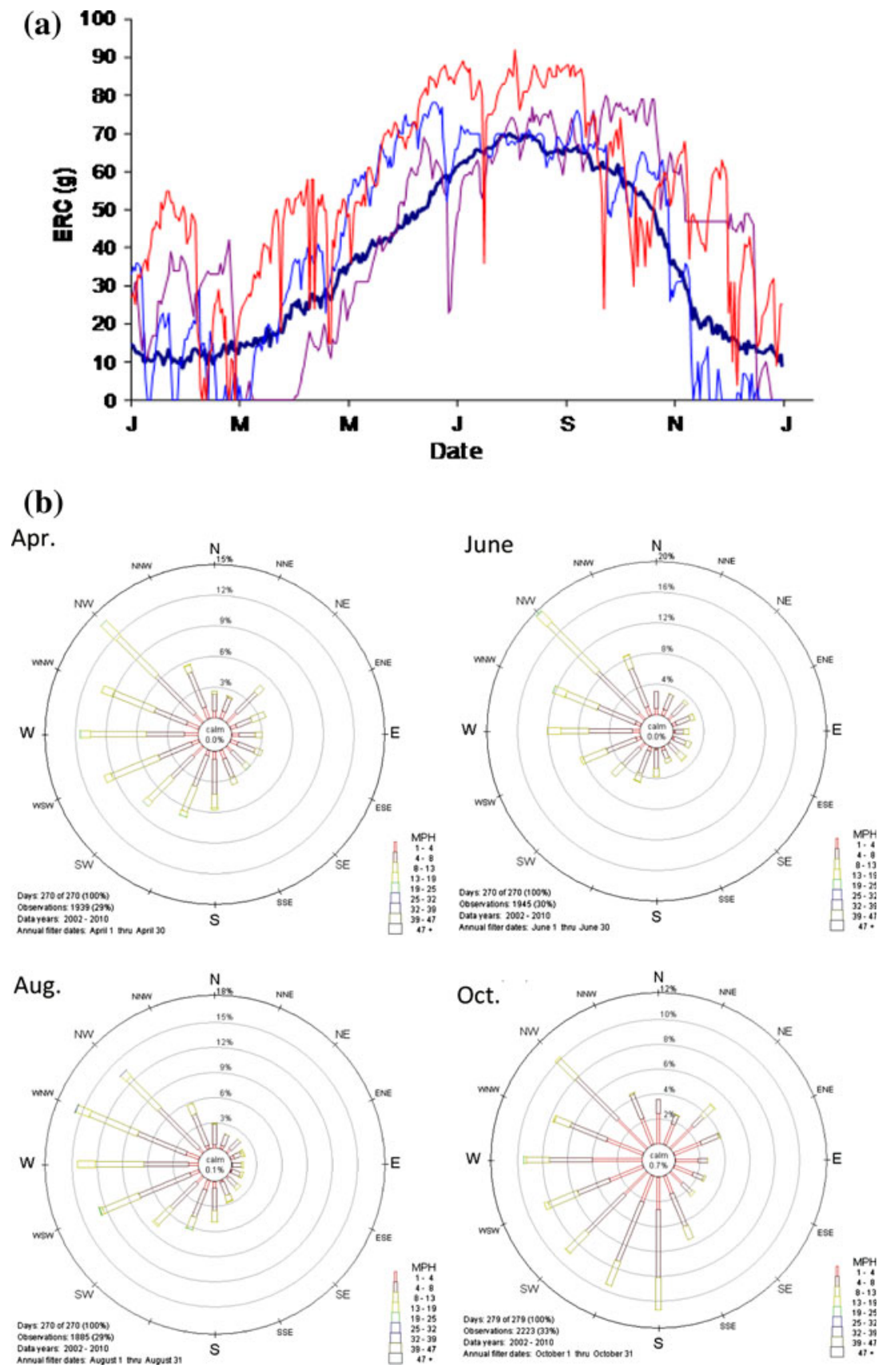

\subsection{Large fire occurrence}

The utility of fire danger indices, such as $\mathrm{ERC}(\mathrm{G})$, for predicting fire activity is often evaluated by means of logistic regression (Bradstock et al. 2009; Martell et al. 1987; Preisler et al. 2004, 2009). Logistic regression was used here to develop a probabilistic relationship between daily $\operatorname{ERC}(\mathrm{G})$ and large fire occurrence from the historical record for each FPU (Andrews et al. 2003). The locally determined size-limit of a large fire or escaped fire varies by FPU and is listed in Table 1. The resulting functions indicate that larger fires are less likely than smaller fires for a given ERC(G) (Fig. 4a). Although there is no exact definition of what constitutes a large fire, these regressions provide a practical and non-spatial method of stochastically simulating occurrence of large fires in relation to seasonal and daily weather variability generated by the time-series model described in the previous section. Fire occurrence is, of course, only conditionally dependent upon fuel moisture, meaning that many other factors such as ignition sources are also relevant (Brillinger et al. 2006; Preisler et al. 2004).

Two statistics are used here to characterize large fire occurrence for each FPU: 


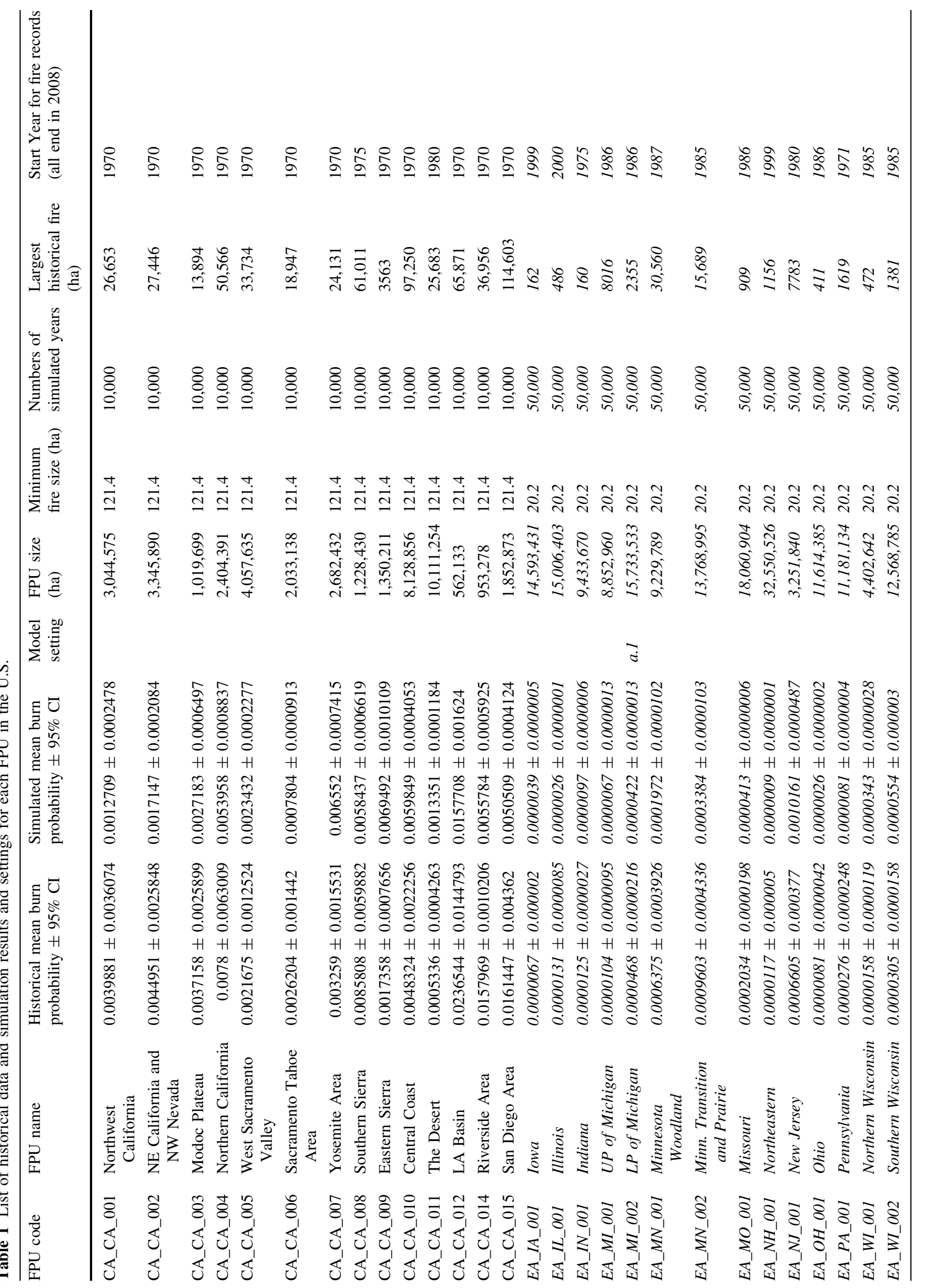




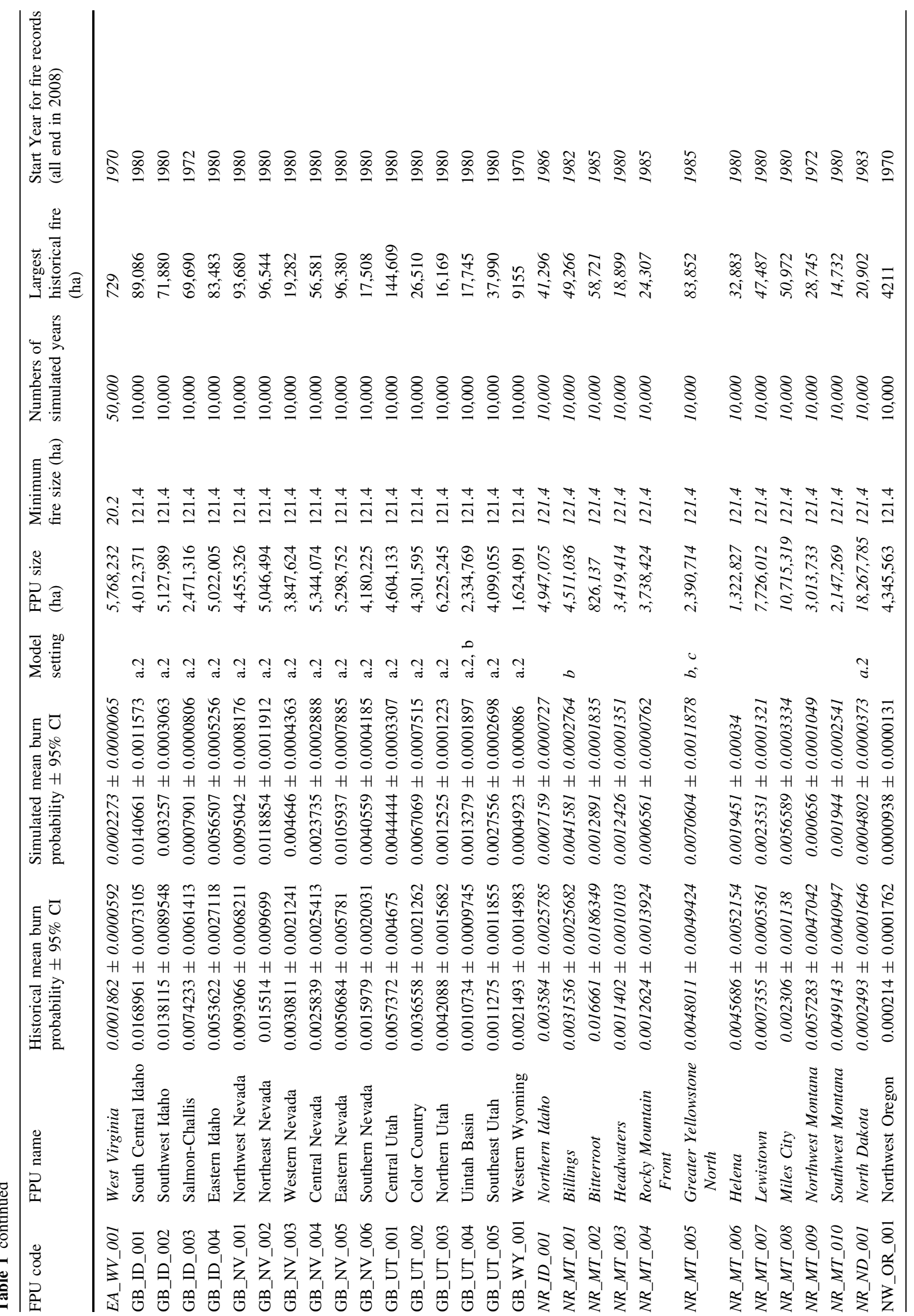




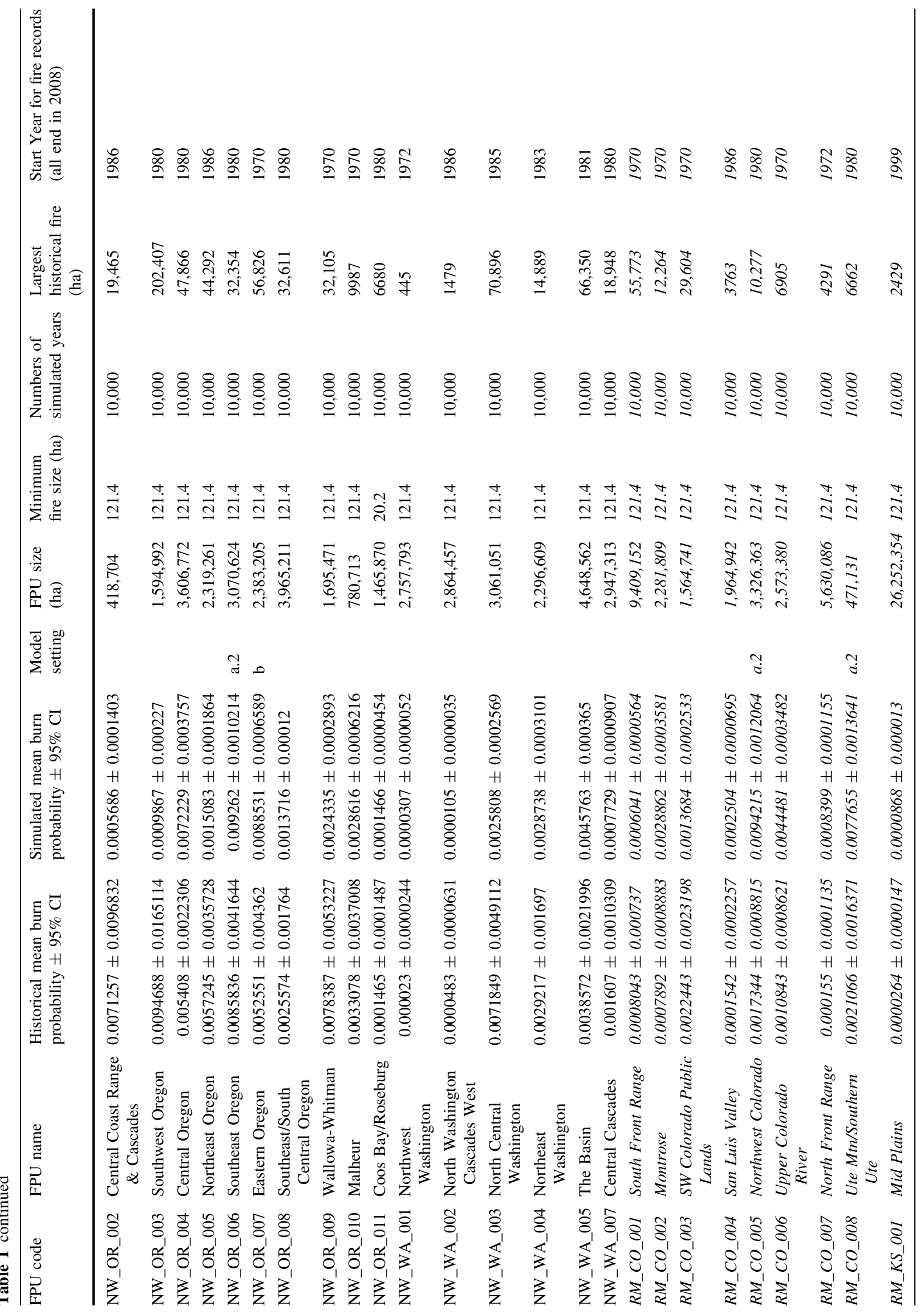




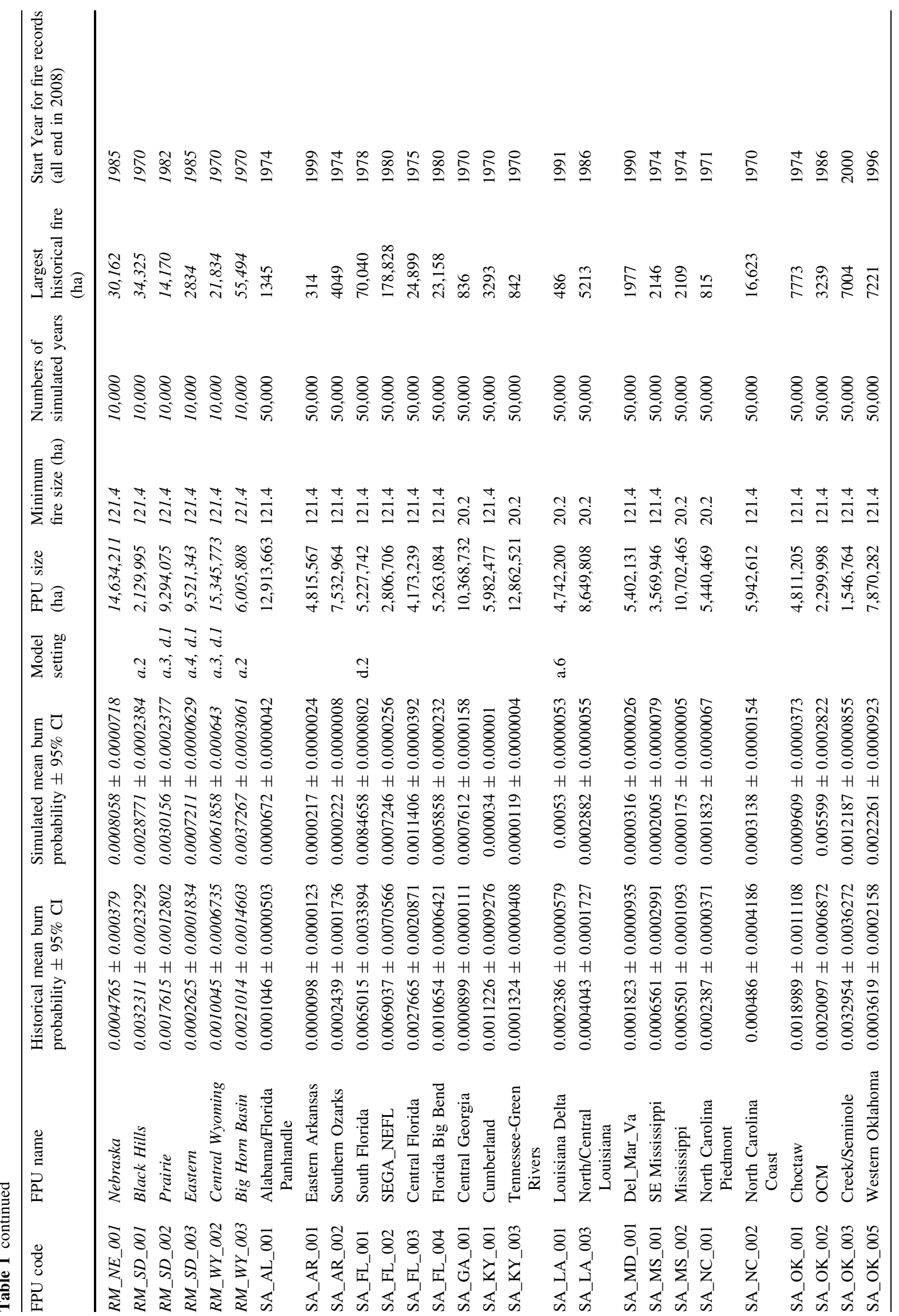




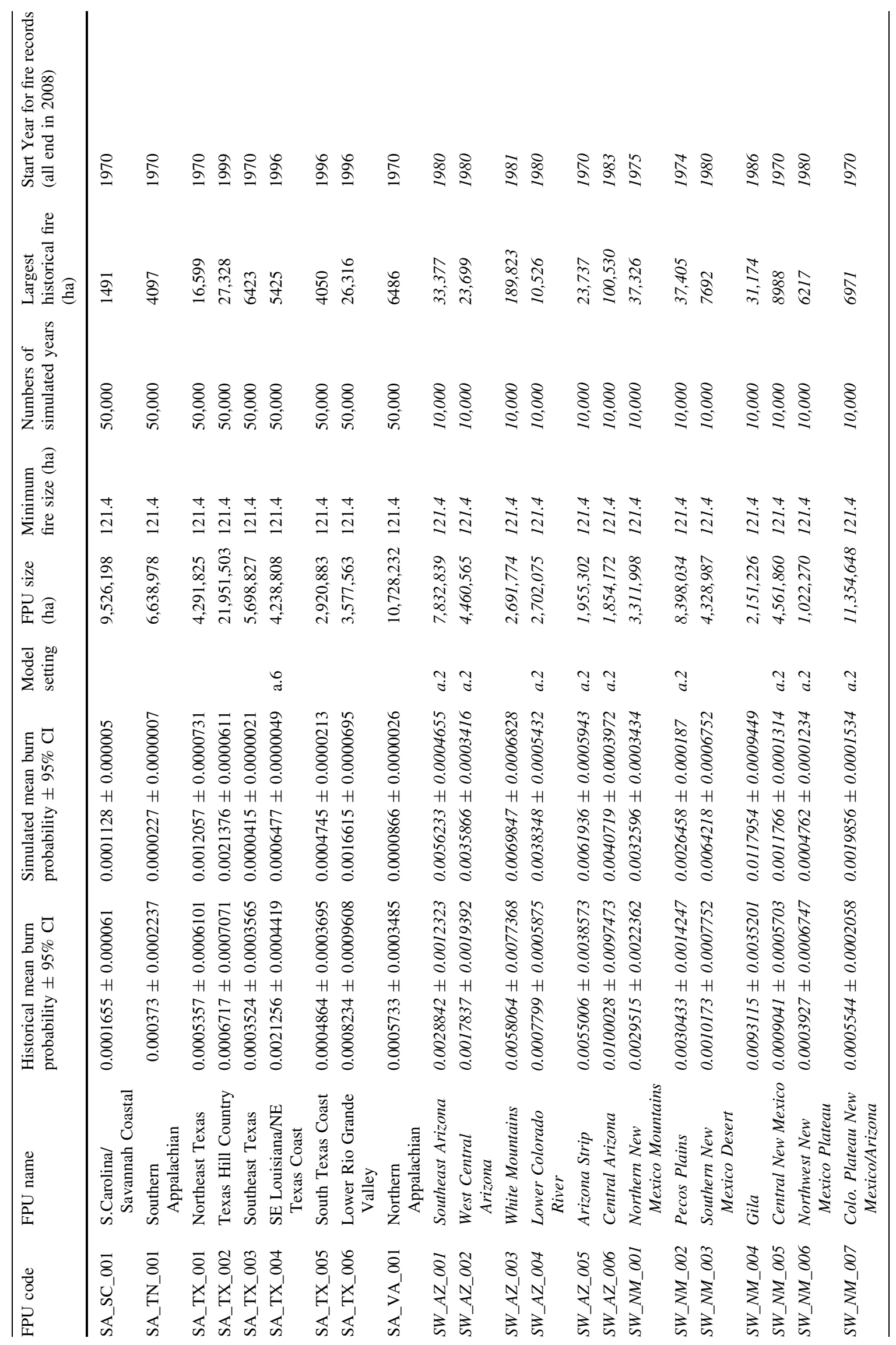




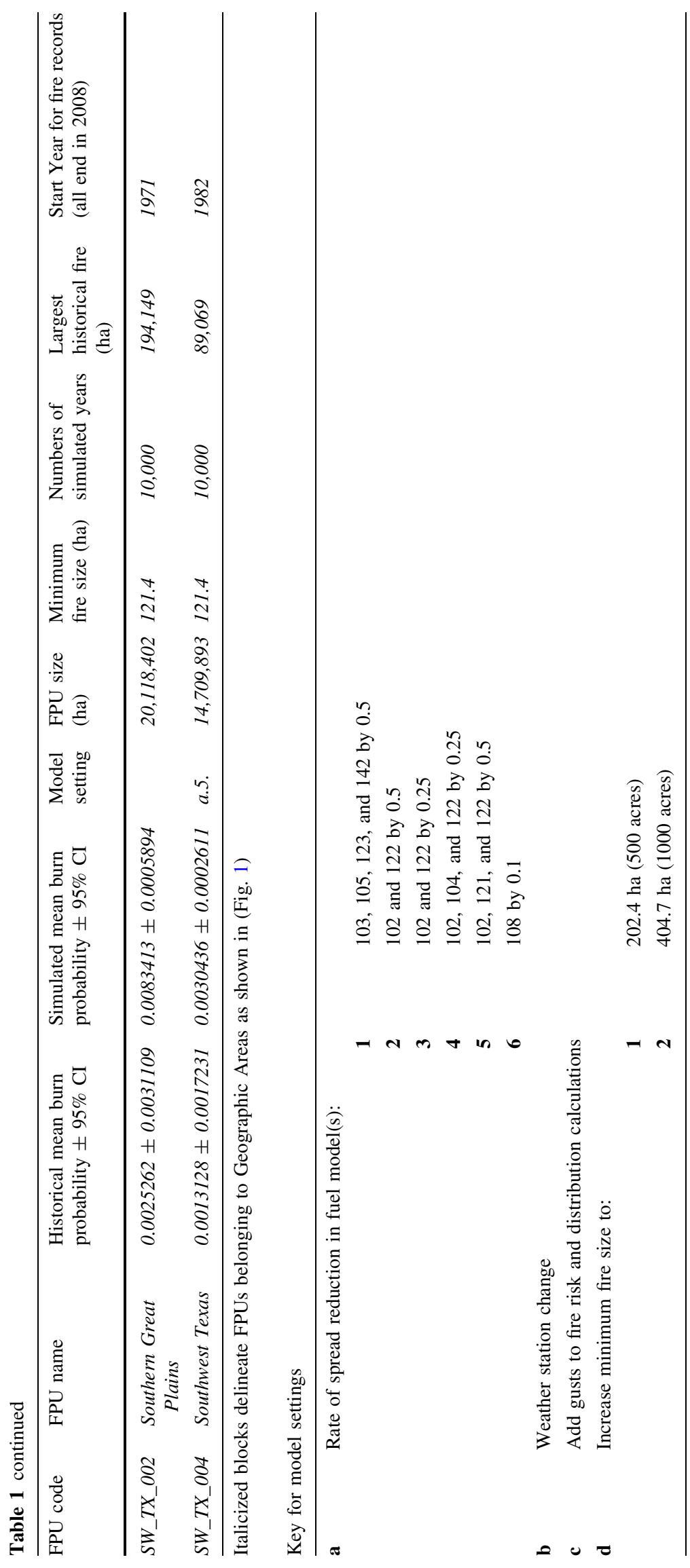



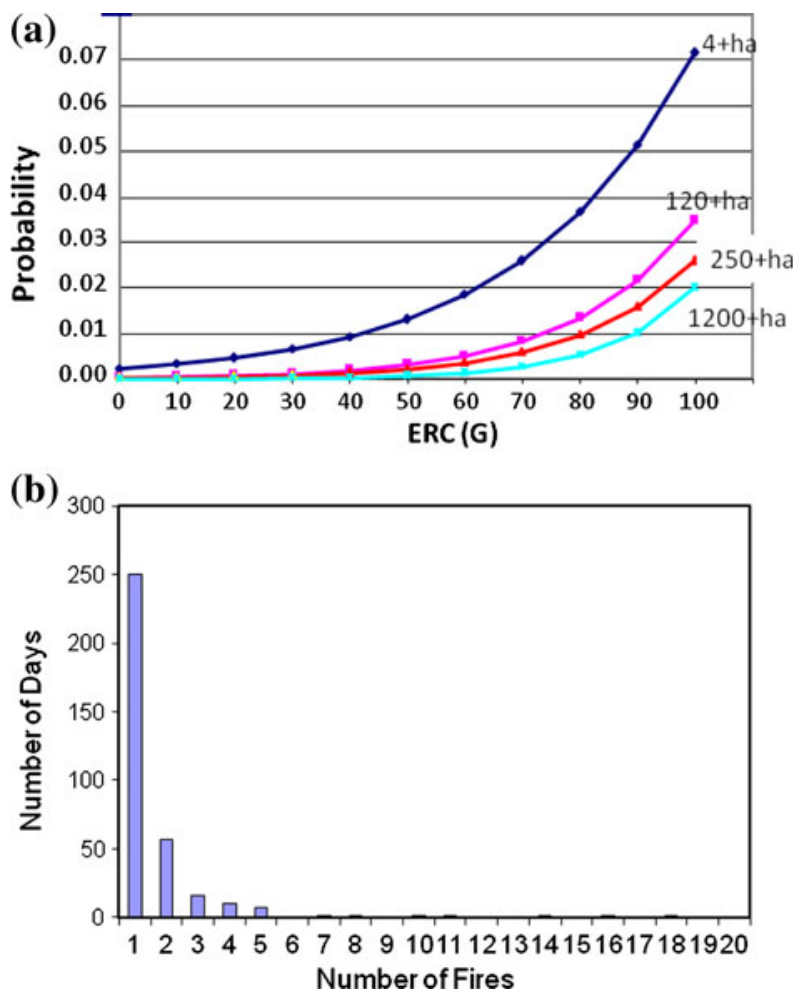

Fig. 4 Example data required to model large fire occurrence in each FPU include a logistic regression predicting the probability of at least one large fire start as a function of ERC, and $\mathbf{b}$ empirical distribution function of numbers of daily large fire starts occurring simultaneously. These data reflect the rarity of simultaneous large fire occurrence, with only one observation in each category of $7,8,10,11$, 14, 16, 18 large fire occurrences in a single day
(1) The probability of at least one large fire start occurring on a particular day as predicted by ERC $(G)$ through logistic regression (Fig. 4a), and

(2) The probability of different numbers of simultaneous large fire starts occurring per day for each FPU (Fig. 4b).

Large fire start locations were determined randomly within FPUs. This simplest assumption was made in the absence of a ready and practical national-scale alternative to derivations from historical large-fire start locations. This simulation system concerns only large fires and spatial refinements will depend on resolution of whether (1) large fire start locations differ from the population of all ignitions as indicated by Dickson et al. (2006) and Syphard et al. (2008), and (2) if large fire locations are independent over time and space. This last factor is critical because large fires are distinguished by their ability to spread, and the recurrence of future large fires may be diminished by proximity to earlier large fires until fuel conditions recover (Rollins et al. 2001; Collins et al. 2007). This would mean that historic large fire occurrence locations may only be generalizable as probability density functions for use in risk assessment at very coarse resolutions.

\subsection{Fuels and topography}

Spatial information on fuels and topography was obtained at $30 \mathrm{~m}$ resolution from the LANDFIRE project (http://www. landfire.gov). Data layers include descriptions of surface
Fig. 5 National U.S. map showing surface fuel models (Scott and Burgan 2005) at $30 \mathrm{~m}$ resolution as contained in the LANDFIRE data set (http://www.landfire.gov). All simulations were performed after resampling data to $270 \mathrm{~m}$

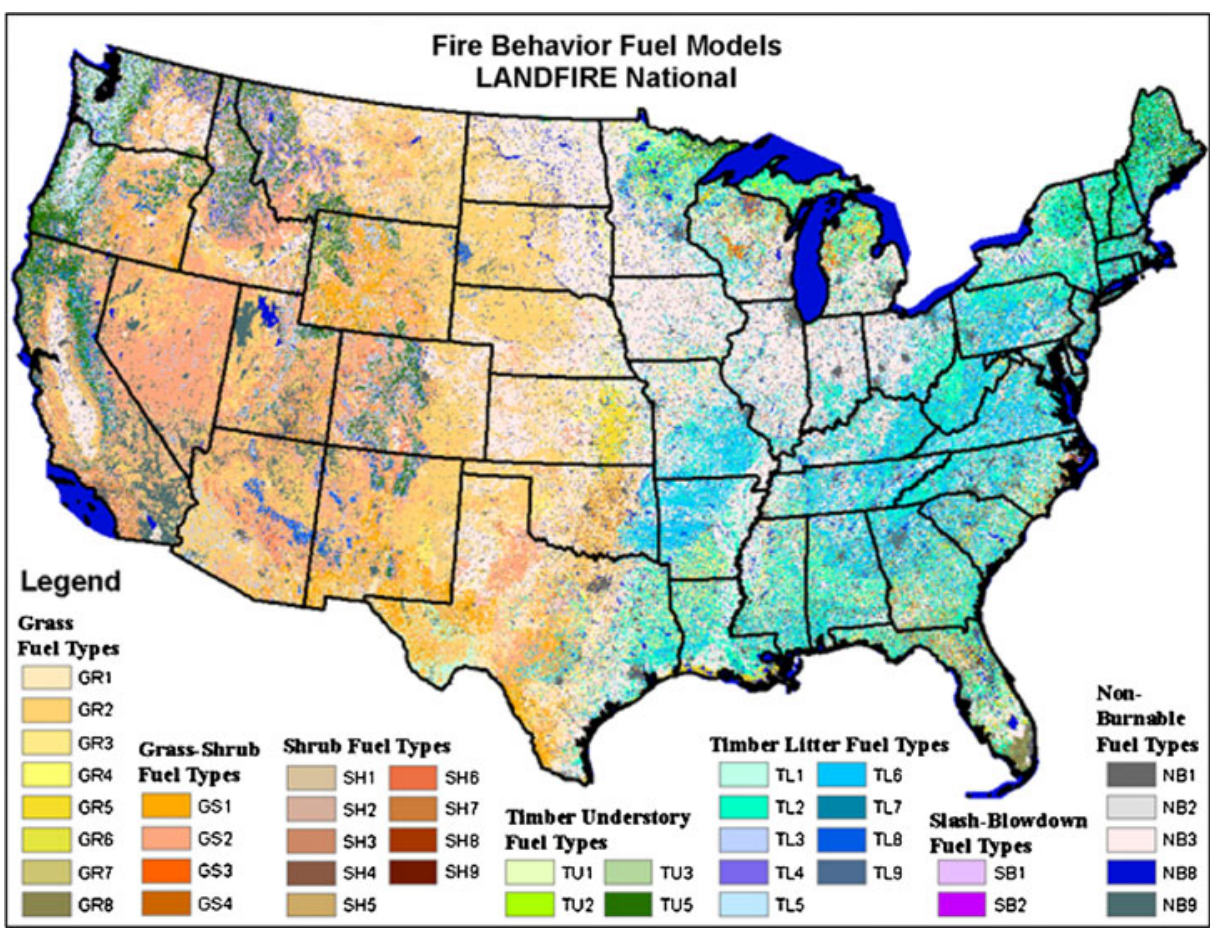


(a) No Timber Fuel Types Present

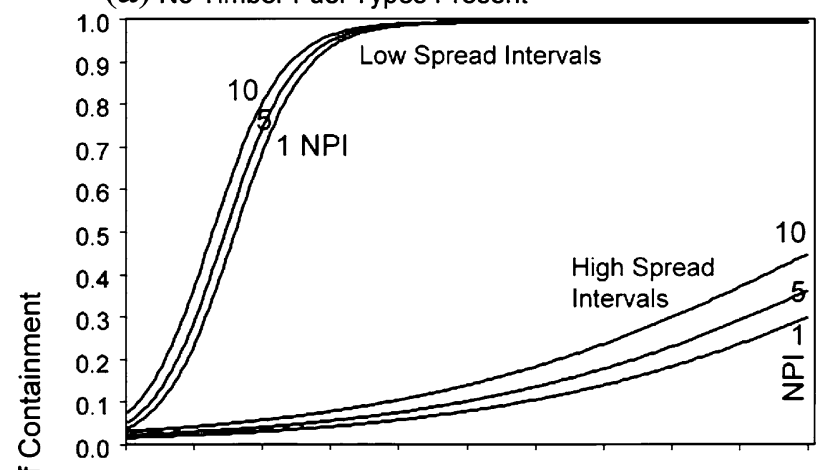

(b) Timber Fuel Types Present

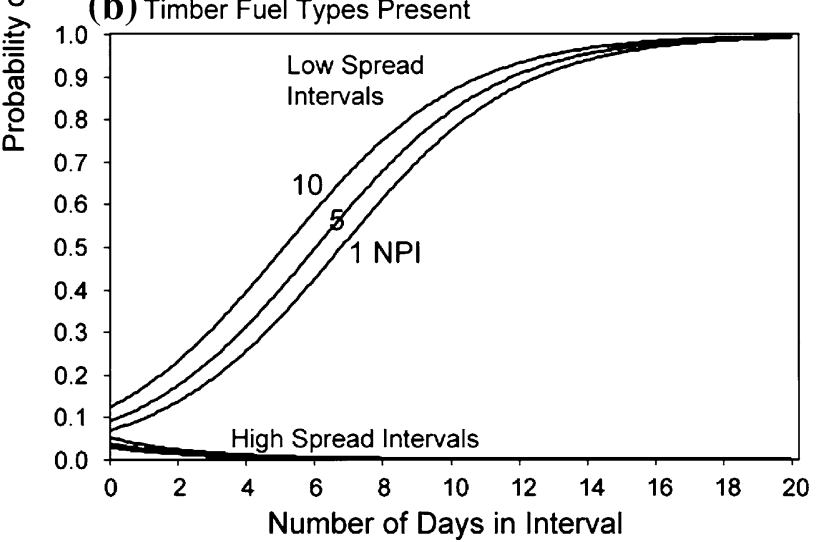

Fig. 6 Statistical model of large fire containment for fires burning in $\mathbf{a}$ grass and shrub fuel types and $\mathbf{b}$ in timber fuels (from Finney et al. 2009). NPI number of previous intervals

fuels (Scott and Burgan 2005) and canopy fuels in formats required by fire growth simulation software (Finney 1998, 2006). There were 134 FPUs in the continental U.S. which varied from 418,704 ha to 32,550,526 ha in area (Fig. 1, Table 1). Data from LANDFIRE are originally produced at $30 \mathrm{~m}$ resolution (Fig. 5) but all data were resampled to $270 \mathrm{~m}$ to achieve practical simulation times. For purposes of simulation, the national dataset was clipped to the spatial extent of each FPU plus a buffer area of $15 \mathrm{~km}$ around all external borders. This buffer area was intended to minimize edge-effects on spatial fire simulations caused by fires starting outside the designated FPU. All buffers were removed prior to analyses of simulation outputs.

\subsection{Large-fire suppression}

The effectiveness of fire suppression on large fire patterns remains poorly understood but cannot be ignored given the huge annual effort and expenditures on large wildland fires (Calkin et al. 2005; Gebert et al. 2007; Liang et al. 2008). The influence of modern fire management policy is represented in this system by means of a statistical model of containment. The model relied on large-fire records from 2000 to 2005 (Finney et al. 2009) to yield a probability of containment related to time periods of high and low fire area growth (relative to the average daily area change). Containment was more likely (1) during periods of slow growth, similar to the findings of Flowers et al. (1983) and Podur and Martell (2007), (2) with increasing fire duration, and (3) in non-timber fuels (Fig. 6). This suppression model was used to generate a sequence of containment probabilities associated with intervals of daily fire growth rates that then stochastically terminated fire growth. The fire suppression algorithm limits the sizes of most fires, especially fires that start early in the season; fires that started near the end of the active season are influenced to a lesser degree by suppression and are more apt to be extinguished due to a number of consecutive days of low ERC $(G)$. Without the containment probability model, fires simulated by this system would continue to grow until the end of the year if weather conditions were favorable.

\subsection{Fire growth and behavior}

Large fire starts were modeled stochastically using the daily $\operatorname{ERC}(G)$ values generated by the time series analysis (Fig. 3a) and the relationship between $\operatorname{ERC}(\mathrm{G})$ and probability of fire occurrence (Fig. 4a). The simulation process begins with the start of the calendar year, day-by-day, determining whether one or more large fires start on each given day, and then simulating growth of fires that occur. The locations of large fires are assumed to be random, but if data were available and indicated otherwise, the spatial pattern of ignitions could be adjusted accordingly. Each fire initiated on a given date was grown from its ignition point using the sequence of daily values of fuel moisture and wind speed from the synthetic weather stream for the corresponding calendar period. The duration of fire growth was determined only by the weather sequence following the day of ignition and by the suppression model (i.e., fire duration was not set a priori). This contrasts with methods for modeling burn probability which rely on parameterization of the burn duration based on historical fire data (e.g., Parisien et al. 2005; Parisien and Moritz 2009; Ager et al. 2007; Braun et al. 2010).

For each fire, a minimum travel time (MTT) algorithm performs fire growth by searching for the shortest fire travel times among nodes of a regular lattice overlain across a landscape (Finney 2002). This method minimizes distortion to fire shapes that results from cellular automata or gridded contagion algorithms (Ball and Guertin 1992; Peterson et al. 2009). The original MTT algorithm was enhanced to permit time-varying burning conditions and include spotting from torching trees (Albini 1979). It calculates fire behavior (e.g., fireline intensity) at each "node" or cell corner of a gridded landscape, which is necessary for determining fire effects. Fireline intensity varies 
considerably for each node based upon (1) the different weather conditions occurring at the time the fire burns each pixel, and (2) the direction the fire encounters a pixel relative to the major direction of spread (i.e., heading, flanking, or backing fire).

To make the fire growth simulation efficient, fire behavior for the entire landscape was pre-processed for all combinations of moisture (three percentile categories: 80th, 90th, and 97th $\operatorname{ERC}(\mathrm{G})$ percentiles) and wind speeds and directions for each month described above. For example, the total number of fire behavior conditions for 3 ERC $(G)$ percentiles, 5 wind speeds, and 8 wind directions would be 150 (plus three scenarios for calm wind). These fire behavior calculations (Finney 1998, 2006) yield the spread and intensity of surface fire (Rothermel 1972), crown fire (Rothermel 1991; Van Wagner 1977), and spotting distances from torching trees (Albini 1979). Preprocessing of fire behavior improved the efficiency of the system because the calculations could be parallelized and the results stored for repeated access by the fire growth algorithm for all of the many fires simulated in the ensemble. To further enhance efficiency, only the data essential for determining fire growth and intensity for each fire weather scenario were stored. These include the elliptical fire dimensions (Finney 2002), direction of maximum spread, maximum fire line intensity (Byram 1959), and maximum spotting distance and direction.

The ensemble simulation system was developed for shared-memory computers and parallelized with multithreading among the independent Monte Carlo simulation years. Computers used for the simulations contained 16 or 32 processors with $32-64$ GB of shared memory. Computing times were dependent on the number of years in the simulations (set at 10,000 or 50,000 for all FPUs), the resolution of the spatial data $(270 \mathrm{~m})$, and the sizes of the fires that developed.

The output variables stored from each run included (1) the burn probability at each $270 \mathrm{~m}$ cell as determined by counting the number of times each cell burned and dividing by the total number of simulation years, (2) the size distribution of all fires in each FPU, and (3) the conditional probability distribution of flame length for each $270 \mathrm{~m}$ cell. Flame length $(\mathrm{m})$ is an empirical transformation of fireline intensity based on Byram's (1959) equation and is more interpretable than units of $\mathrm{kW} \mathrm{m}^{-1}$. Burn probability outputs were also summarized as averages for each FPU.

\subsection{Comparison with historical fire records}

Observational data were obtained from both federal and non-federal fire-occurrence reporting systems as described by Brown et al. (2002) and Schmidt et al. (2002). Federal fire records were drawn from the USDA Forest Service Fire
Statistics (FIRESTAT) system via the National Interagency Fire Management Integrated Database (NIFMID), from the USDI Wildland Fire Management Information (WFMI) database, and from the Fish and Wildlife Service Fire Management Information System (FMIS). Non-federal fire records were drawn from the National Association of State Foresters (NASF) fire records database and the National Fire Incident Reporting System (NFIRS). The spatial and temporal coverage and information content of records within the non-federal fire reporting systems varied by state (see Schmidt et al. 2002), and, when possible, missing data were acquired from state fire-management offices. The resulting dataset compiled for this analysis included fire records from circa 1970 through 2008, but originating years varied by FPU (Table 1). This time span corresponds well to the weather station data obtained used for fire simulations.

Fire occurrence records are prone to inconsistencies between jurisdictions (Schmidt et al. 2002) because of the differing requirements for reporting, accessing, and recording specific attributes such as ignition location and details such as sizes and duration. To be included in this analysis, a fire record had to include a point location at least as precise as the centroid for the Public Land Survey System (PLSS) section in which the fire occurred, the date on which the fire was discovered, and the final fire size. Viable records were then screened for obvious geospatial and information errors (e.g., nonvalid dates). When sources of geospatial errors could be identified (i.e., improper formatting of coordinates, incorrect spatial reference provided), the location information was corrected and those records salvaged. Redundant records, which are present within individual reporting systems and further generated via compilation of data from multiple systems (Schmidt et al. 2002) were painstakingly identified and removed. Information and geospatial errors and redundant data may persist, of course, but errors of omission, especially for smaller non-federal fires, are much more probable and cannot be known. The largest fires (ca. $>2000$ ha), which collectively can account for more than $95 \%$ of the total area burned on an annual basis (Strauss et al. 1989), tend to be multi-jurisdictional incidents and are the most likely to be included in the compiled database, even with missing non-federal records, as long as the federal record is complete. Based on trends indicated by Brown et al. (2002) and guidance from the national Fire Program Analysis (FPA) system, we determined that the federal record could be considered complete only for the period 1992-2008. Thus, while the resulting national dataset still may be incomplete, it should afford reasonable estimates of annual area burned from 1992 through 2008 due to the high probability that records of the largest fires are included. 
Two metrics for comparing the simulations with observations were (1) average burn probability for each FPU, and (2) the fire size frequency distributions for each Geographic Area (or GA, a regional collection of FPUs) (Fig. 1). This aggregation of historical fires across the larger domain of the GA was necessary because of the paucity of large fires at finer scales. GAs were originally delineated as administrative units for organizing fire suppression activities (http://gacc.nifc.gov) but are not homogenous in terms of fire activity or climate. Two pairs of GAs (Northern and Southern California, and the Eastern and Western Great Basin) were combined for the analysis for a total of $8 \mathrm{GAs}$ in the continental U.S. Average annual burn probabilities were calculated for each FPU by adding all area burned from 1992 through 2008 and dividing by the total area in each FPU and the 17 years of record. The average burn probabilities calculated this way correspond to the Natural Fire Rotation concept of (Heinselman 1973) which assumes a stationary climate, spatially uniform ignition and burning conditions, and constant level of suppression activity. The assumed stability is impossible to verify, but given the dearth of other sources of information, the historical averages of burn probability derived were deemed satisfactory for comparisons with the results of our simulation.

To ensure that our modeled burn probability has parameters consistent with observed historical records, we employ the method of bootstrapping (Efron and Tibshirani 1986) to form confidence intervals around both the modeled burn probability and the historical burn probability. Our bootstrapped resampled datasets yielded estimates of the mean area burned. The standard deviation of those resampled estimates produces the standard error of the estimated area burned. We then divide the mean area burned, and the upper and lower bounds of the estimated mean by the area of each FPU to obtain the confidence intervals of the historical and modeled burn probabilities (Table 1).

Fire size distributions were compiled from the simulation data for each FPU and plotted on logarithmic axes along with the historical distribution of fires combined from all FPUs in each GA. The slope of each log-transformed distribution was obtained by robust regression using Kendall's Tau statistic (Sen 1968) which does not assume normality of the residuals. We used the median frequency in each size category as the dependent variable instead of the actual frequencies which are sparse for the larger fire sizes. Both historical and simulated fire size distributions contained zero observations in some of the largest size categories because such fires are so rare and estimates based on the necessarily small sample sizes of fires in the largest classes are relatively error-prone. The sample size limitation also produces an identical number of fires (often 1 or 2) in size classes in range of the largest fires. The $95 \%$ confidence intervals for the slope coefficients were estimated for evaluating the comparability of slopes.

\section{Results}

Simulation time for FSim to be completed for each FPU varied from about $4 \mathrm{~h}$ to about $24 \mathrm{~h}$ depending on the size of the FPU and the number of years specified for the simulations (Table 1). This was considered a practical level of performance given that the continental U.S. consisted of 134 FPUs.

Both the historical data and model output indicate that burn probabilities averaged by FPU were substantially higher in the western U.S. than the rest of the country (Fig. 7a). This is primarily a result of the lower fuel moistures and much larger fires possible in the vast wildland areas of the west. The average burn probability from each FPU spanned four orders of magnitude $\left(1 \times 10^{-5}\right.$ $1 \times 10^{-2}$, Fig. 7, Table 1) with a high degree of association between the modeled and historical burn probabilities. The smaller sample sizes for historical burn probabilities contributed to much wider confidence intervals than for modeled probabilities (Fig. 7c). While of value, the FPUlevel summaries obscure the underlying finer-scale probability structure (Fig. 7b) that better reflects local vegetation and fuel distribution including developed areas that are mapped as having no flammable vegetation (Fig. 5). Detailed examination by Geographic Area of simulated burn probabilities at the original resolution of $270 \mathrm{~m}$ revealed some localized values as low as $1 \times 10^{-6}$ (Fig. 8Aa-Ha). Simulated burn probabilities compared reasonably with historical data for most FPUs (Fig. 8Ab$\mathrm{Hb}$ ). Discrepancies in burn probabilities within the Rocky Mountain GA (Fig. 8Fb) and the Southwest GA (Fig. 8Hb) showed a tendency for simulated probabilities to be higher than those estimated from historical data.

Observed and simulated fire size distributions for FPUs in each Geographic Area were all found to have nearly linear negative slopes when plotted on logarithmic axes (Fig. 8Ac, d-Hc, d). Of the two parameters that characterize frequency-magnitude distributions, the slope captures the relative frequency of fires of different sizes, while the intercept changes with respect to the total number of fires. In this case, the slope is the parameter of interest, since it characterizes the distribution of large and small fires in each FPU and GA. The slope of historical fire size distributions was between about -1.4 and -1.6 for all GAs, considering the $95 \%$ confidence intervals. Some FPUs displayed obvious differences compared to the historical distribution for the GA, particularly in the Southeast 

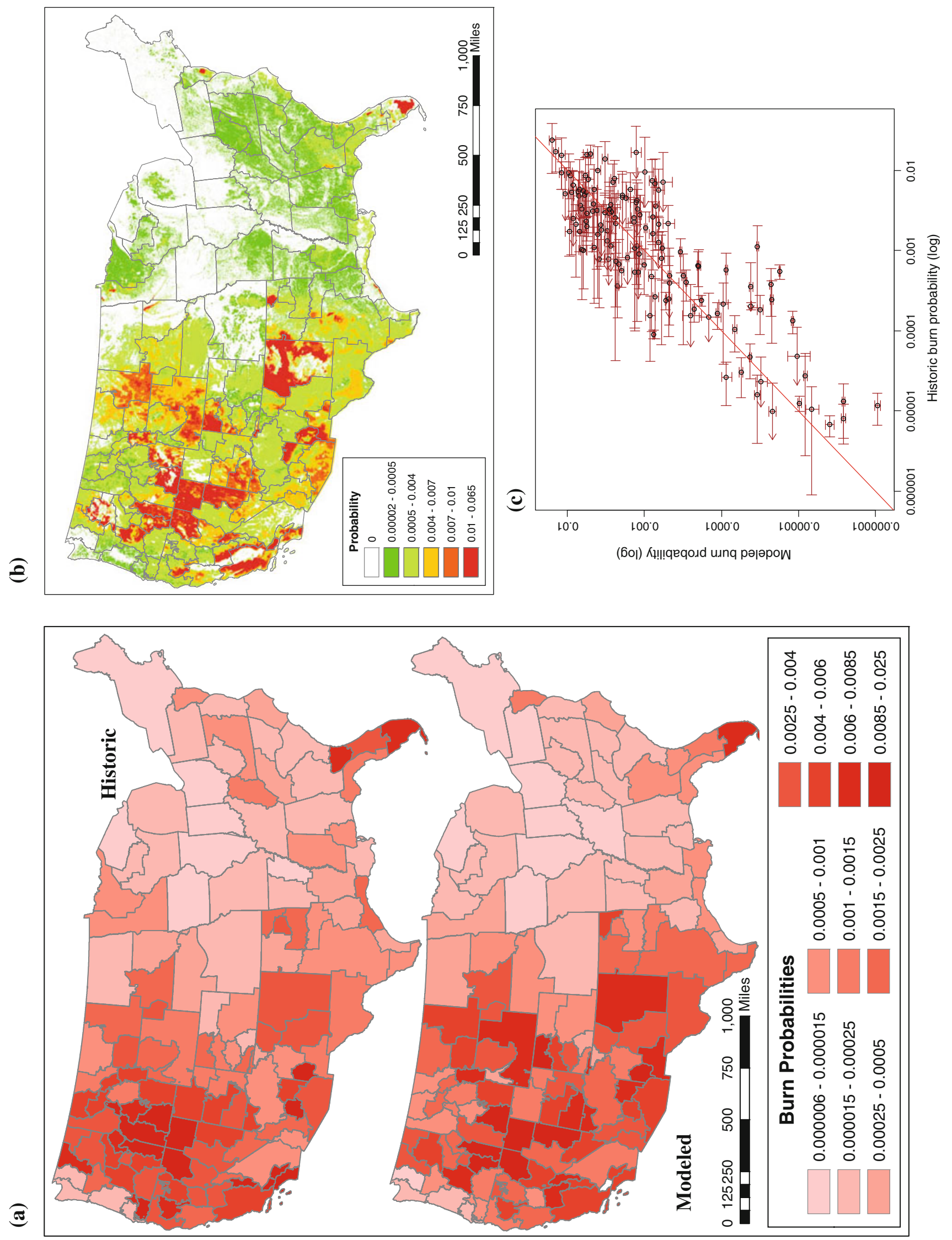
Fig. 7 Results of simulated burn probabilities a compared spatially to historical burn probabilities for the continental United States by FPU, b displayed at native $270 \mathrm{~m}$ resolution, and compared to historical probabilities with $95 \%$ confidence intervals

(Fig. 8Gc, d) and the Northeast (Fig. 8Bc, d). Others GAs were more consistent, for example California GA (Fig. 8Ac, d), the Northwest GA (Fig. 8Ec, d) and the Rocky Mountain GA (Fig. 8Fc, d). Expectedly, the numbers of fires for each GA based on the 20-30 year historical record were much lower than those based on 10,000 to 50,000 simulation years, causing the historical data curve to plot below the data from each FPU. Exceptions include a few FPUs in coastal areas in the Pacific Northwest GA (Fig. 8Ec) and in the heavily agricultural FPUs in the Rocky Mountain GA (Fig. 8Fc). However, the maximum simulated sizes were much larger than the maxima from historical records, some of which could be a product of rare sequences of fire weather and ignition locations that have not been observed.

The agreement between simulated and observed fire size distributions was partly a function of the fire containment model (Fig. 9). Containment probabilities had the effect of reducing the sizes of fires by censoring growth after quiescent periods (Fig. 9c-f). This caused a greater fraction of fires to be of smaller sizes and increases the slope of the fire size distribution.

Fire behavior variability was expressed in terms of conditional probabilities of flame length (Byram 1959) in $0.66 \mathrm{~m}$ categories for each $270 \mathrm{~m}$ cell (Fig. 10). The conditional probabilities from all six categories sum to 1.0 and can be multiplied by the actual burn probability to produce absolute probabilities. The national maps (Fig. 10) suggest that low flame length potential dominates eastern forests whereas high flame length potential is far more common in the western U.S.

\section{Discussion}

The spatial simulation of wildfire burn probabilities for an area the size of the continental U.S. has not been previously attempted. As demonstrated here, however, it is becoming practical from both the standpoint of computing requirements, data availability, and modeling components. This effort was driven by the practical desire for a modeling process for large-scale risk assessment, but the results also offer the opportunity to investigate fire patterns and their causes over large spatial domains. For operational purposes, model estimates of burn probability had to be accurate enough to warrant confidence and be robust to the range in quality and quantity of standardized sources of input data routinely available. Only a limited set of metrics were available to make comparisons of the model results, and these included the historical burn probabilities summarized by FPU and the fire size distributions.

With a few adjustments (Table 1), the system was capable of generating output that corresponded well to the patterns and trends evident from historical fire records. An important limitation to model evaluation for such a large and heterogeneous land area such as the continental U.S. is the reliability, consistency, and time-span of historical fire records, as well as the annual variability in fire activity expressed by the confidence intervals (Table 1). Our static approach to the simulation of probabilistic risk assumes that the extant landscape structure and climatology can be used to approximate patterns of fire occurrence for a span of decades during which human land usage and fire management policies were in some degree of flux. So it is interesting that conditions which contributed to the historic fires (ignition sources, land cover types and fire spread patterns) appear to be generalizable beyond that time period and specific landscape pattern. Cui and Perera (2008) imply that the variability in ignition, land use, and suppression should influence actual fire size distributions. This contradiction might be partly explained by the extreme nature of weather and fuel conditions that drive the large fires; dry and windy conditions overwhelm the sensitivity of fire behavior to fine scale departures from model assumptions experienced under moderate conditions. This is also probably an artifact of modern wildland fire policies which "allow" fire spread only when the capability to suppress them is exceeded. Suppression actions select for the fastest fires under the most extreme conditions and ultimately limit growth to shorter time periods than would occur because of weather or fuel limitations.

The most common adjustment applied to the simulation was alteration of the fire spread rate for two primary grass and shrub fuel types in a minority of the FPUs (Table 1). A few fuel types, mapped by LANDFIRE, were found to produce excessive spread rates and fire sizes. The limited need for these adjustments or calibrations among FPUs suggests that the root issues are fuel-specific or regionspecific, or otherwise these calibrations would be required for a majority of the U.S. Whether these adjustments were required to compensate for the aggregated spatial resolution ( $270 \mathrm{~m}$ grid cells) or temporal resolution (daily weather) is not known. However, both are well understood to affect models of fire growth and fire regimes. For example, fire growth modeling has been reported to overpredict when input weather lacked high-frequency variability (Anderson et al. 2007). The use of weather data from a single station in each FPU may contribute to disparity between observed and predicted burn probabilities. Regarding spatial inputs to the simulation, the spatial scale and patterns of fuel, topographic features, and roads can 
influence fire growth and fire frequency (Gonzalez et al. 2007; Jones et al. 2004; Jordan et al. 2008; Kellogg et al. 2008; King et al. 2008; Viedma et al. 2009; Yang et al. 2008), as well as ignition (Massada et al. 2009; Krawchuk et al. 2006; Braun et al. 2010). Sensitivity analysis of input data resolution and spatial re-sampling algorithms would likely be helpful in determining the relative influence of spatial data and weather influences on modeled fire growth and burn probabilities (Salvador et al. 2001).

The range of modeled and historical burn probabilities estimated here is generally consistent with those from other North American studies. Martell and Sun (2008) reported historical burn probabilities for the years 1976-1994 in Ontario, Canada, that varied from $1 \times 10^{-6}$ to about $1 \times 10^{-2}$, which is almost identical to the range in our findings. Our estimates of average burn probability for the western Geographic Areas were in similar ranges as those for the past century reported by U.S. eco-region $\left(2 \times 10^{-4}-7 \times 10^{-3}\right.$, Littell et al. 2009). National patterns of burn probability indicated here were remarkably similar to those generated from a multivariate statistical model that used both climate and vegetation variables (Parisien and Moritz 2009).

The variability of fire behavior produced by the simulation (Fig. 10) is essential to determining fire effects in an actuarial risk framework (Calkin et al. 2010). Different ecological resources, for example, have different responses across the range of fireline intensity levels. Thus, the simulated fire line distributions at each cell can be used to estimate expected impact (or percentiles) for different ecological resources (Calkin et al. 2010). Expected impacts can be summarized for each $270 \mathrm{~m}$ cell (as displayed in Fig. 10) or, using the intensity "footprints" of each fire, evaluated on a fire-by-fire basis to produce cumulative effects or annual variability in risk within arbitrary land areas or ownerships. Although not simulated here, the system allows for the assessment of effects of management activities on burn probabilities and fire behavior characteristics. By simulating the spread of fires in relation to certain patterns of fuel types under various weather conditions, the consequences of fuel or vegetation management activities, both onsite and "downstream" or offsite can be evaluated (Ager et al. 2007, 2010; Beverly et al. 2009; Collins et al. 2010; Parisien et al. 2005; Graham et al. 2009; Stephens et al. 2009).

The close correspondence between simulated and observed fire size distributions was similar to that reported by Moritz et al. (2005), but probably for different reasons. Both models used weather for simulations but temporal fuel dynamics were specifically modeled by Moritz et al. (2005) and not here. In both cases, fire sizes from the simulation were not simple transformations of the inputs because none directly controlled fire size or duration of
Fig. 8 Detailed comparison of burn probabilities and fire size distributions by geographic area. Panel a shows for each geographic area the burn probabilities from each FPU at $270 \mathrm{~m}$ resolution. Panel b shows observed and simulated average burn probabilities with their 95\% confidence intervals and the line of perfect agreement. Panel c contains the logarithmic plots of the fire size distributions; the legend displays the symbol for each FPU, and in panel $\mathbf{d}$ the slope and confidence interval for each distribution in comparison to the CI (red lines) for the historical distribution aggregated from fires in the entire geographic area

burning. This result, therefore, suggests that the spatial and temporal variability provided to the fire growth model produce joint distributions of fire growth potential that limit fire sizes in a manner similar to natural controls. Specifically the results imply that the distribution of spatial and temporal opportunity for fire growth is what governs the observed power-law distribution of fire sizes (Malamud et al. 1998). In our simulations, these opportunities resulted from the combination of (1) fire weather sequences subsequent to the ignitions as generated by the time-series method, (2) ignition location relative to the spatial fuels/topography patterns, and (3) the statistical probability of successful containment. This interpretation is generally what was proposed by Reed and McKelvey (2002) who argued that competing probabilities of extinguishment and growth could be responsible for the distributions of fire sizes-but not the observed power-law behavior. Our analysis from across the U.S. was consistently supportive of power-law fire size distributions for both historical data and simulated results over the range of fire sizes. The mechanics of this simulation, however, does not allow for the spatial interference of burned patches and areas of available fuel (self-organized criticality or SOC) (Bak et al. 1988, 1990; Malamud et al. 1998; Moritz et al. 2005) because the fuel layers are not updated yearly to reflect burning. This finding is consistent with the idea that a number of different mechanisms may be responsible for the observed power-law behavior besides SOC (Millington et al. 2006; Tebbens and Burroughs 2005). Consistent with the conclusion of Boer et al. (2008), our simulation system suggests that weather sequences exert strong influence over the opportunities for fire growth. Certainly, the extant spatial fuel and topography patterns affected fire sizes and frequencies in our simulation system, just as in nature (Falk et al. 2007; Rollins et al. 2001), but interference among fires (Collins et al. 2007; Moritz et al. 2005) was effectively excluded from our model given that recent fires did not affect the static fuel conditions used for each simulated year. If interference of fire patterns frequently limited the extent of historic fires (van Wagtendonk 1995; Collins et al. 2007), and if we were to account for this phenomenon in our model, then we could see modeled fire-size distributions with steeper slopes than currently produced by the simulations. 

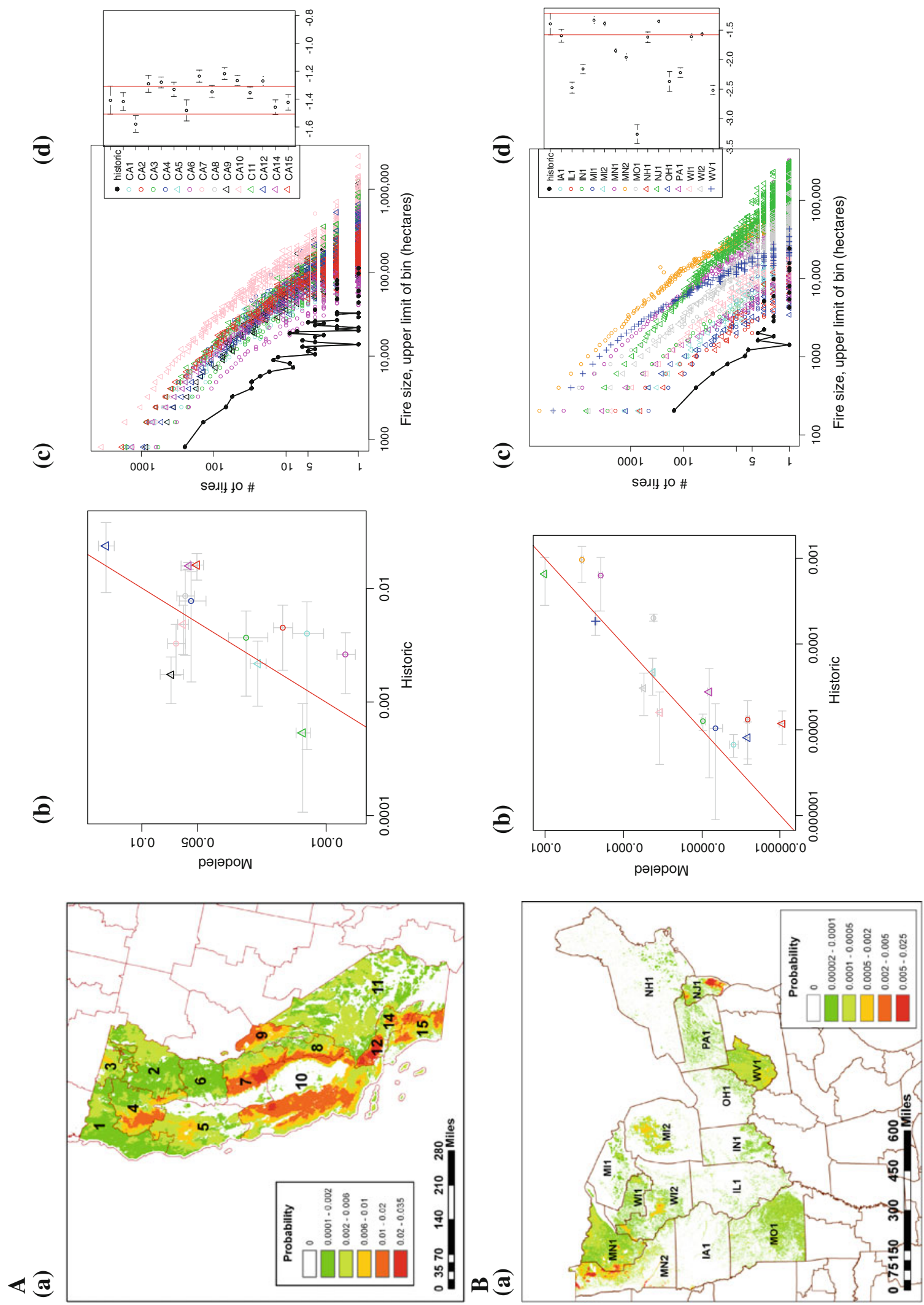

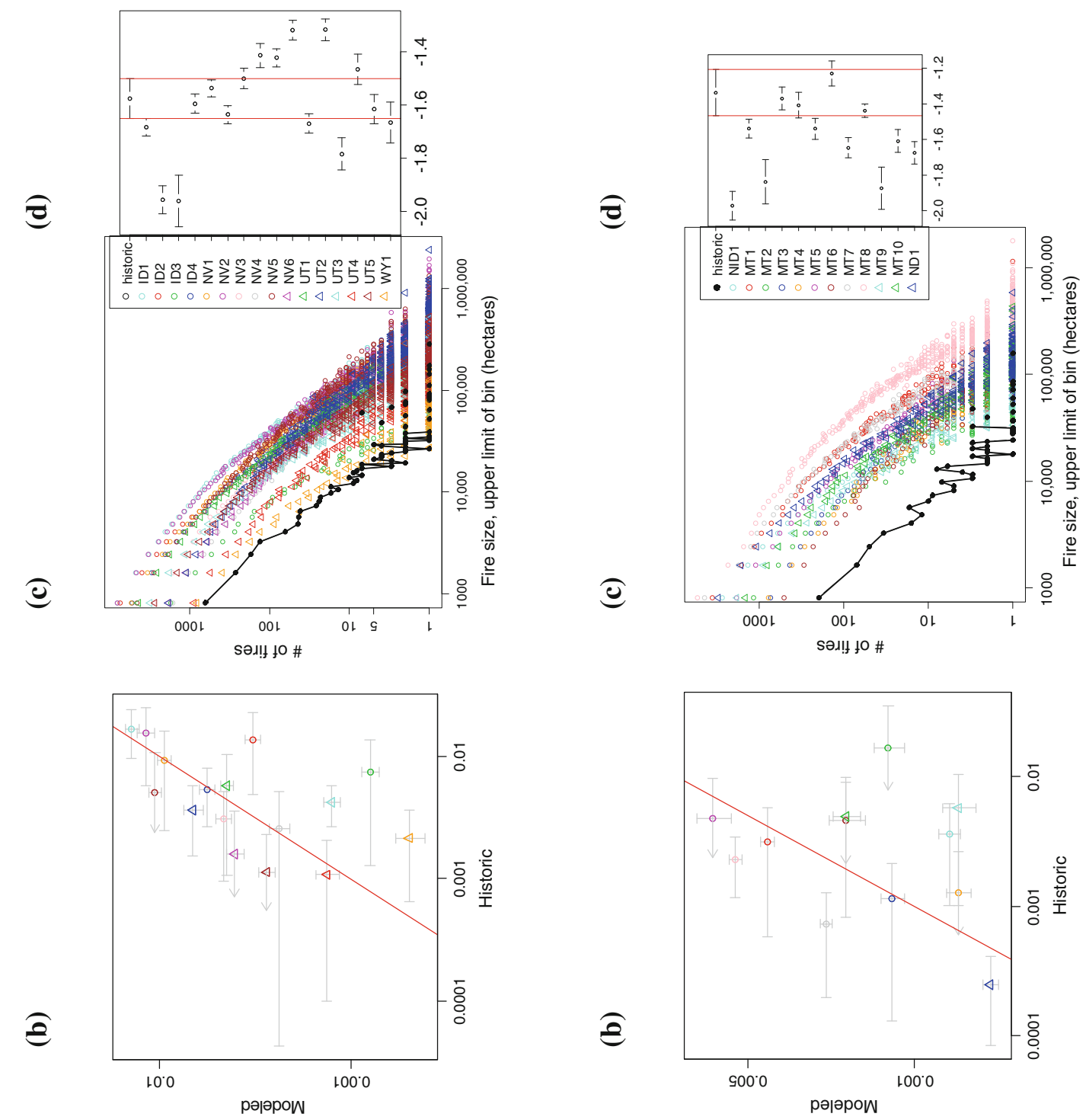

Fig. 8 continued
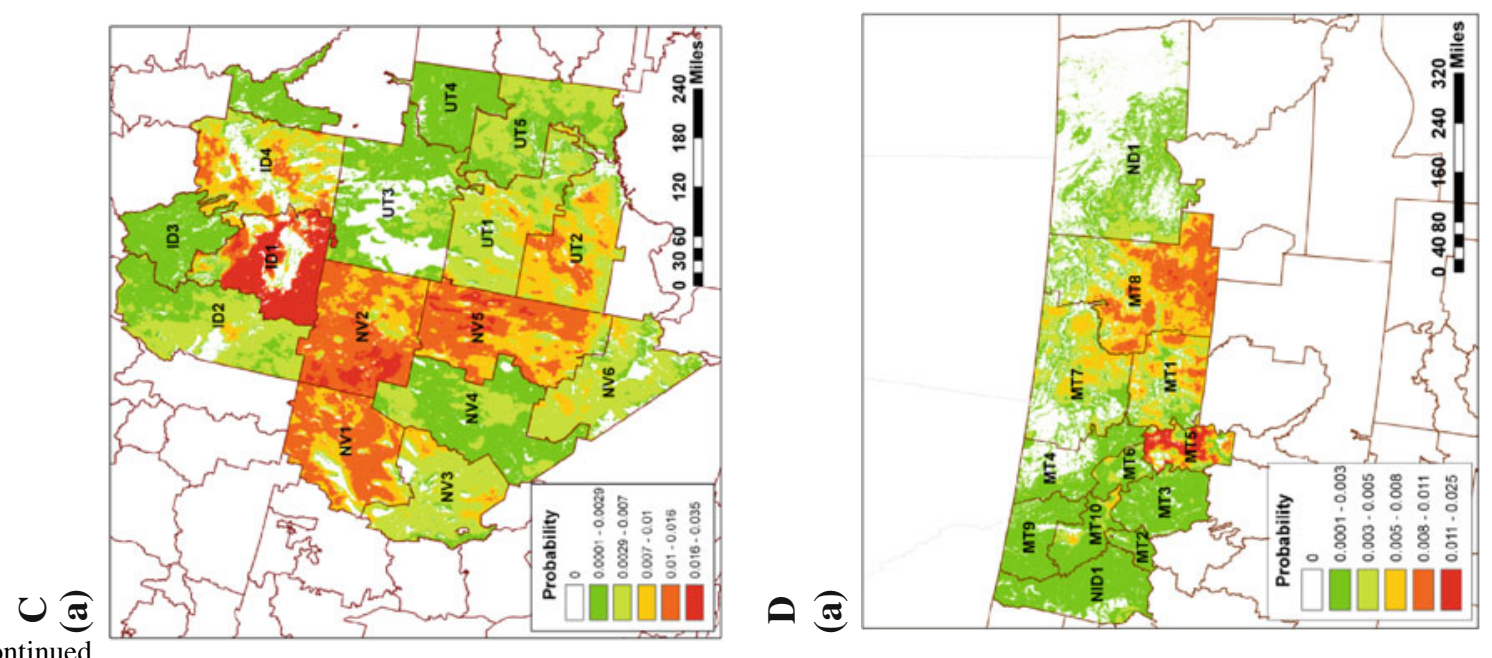

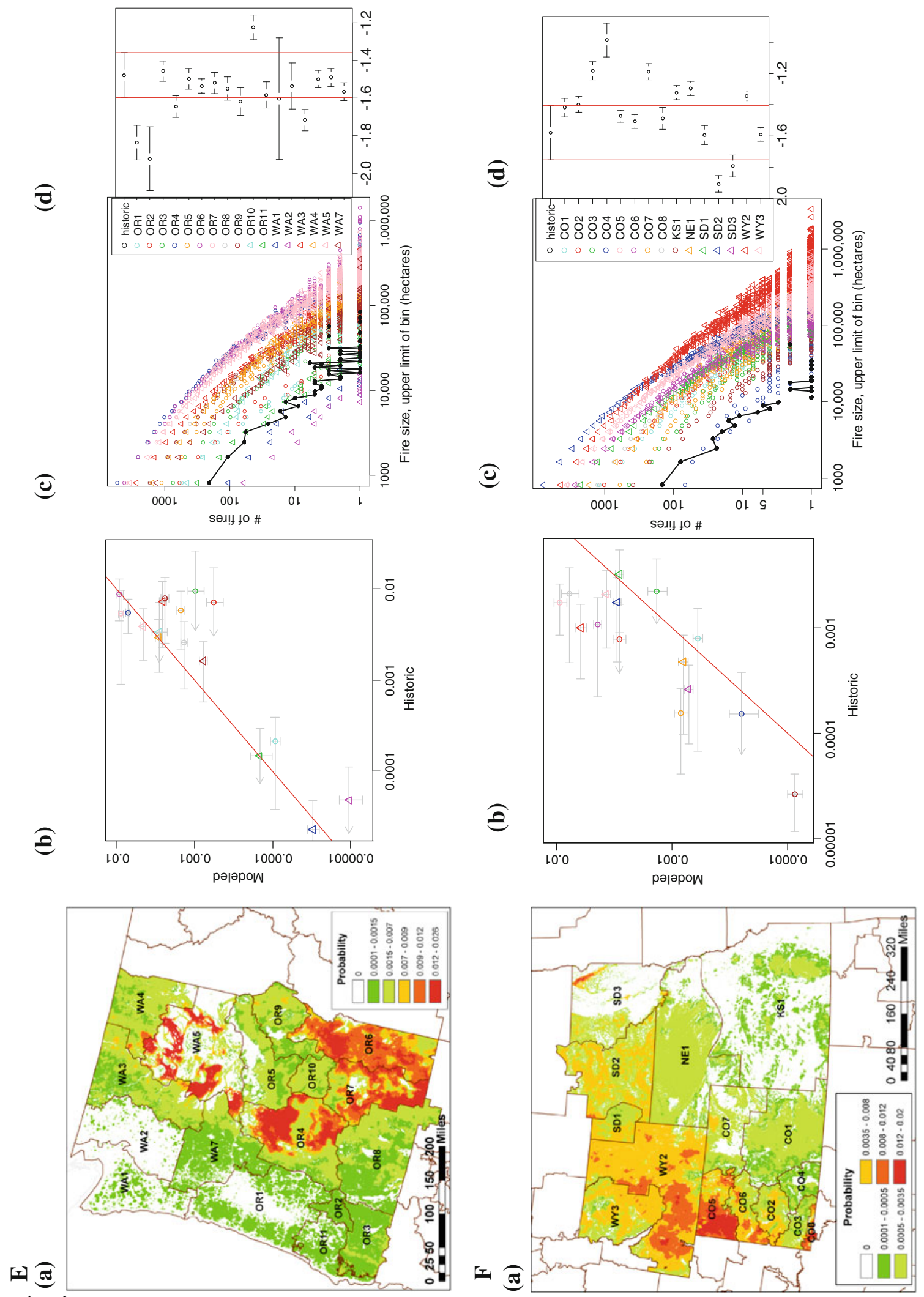

Fig. 8 continued 

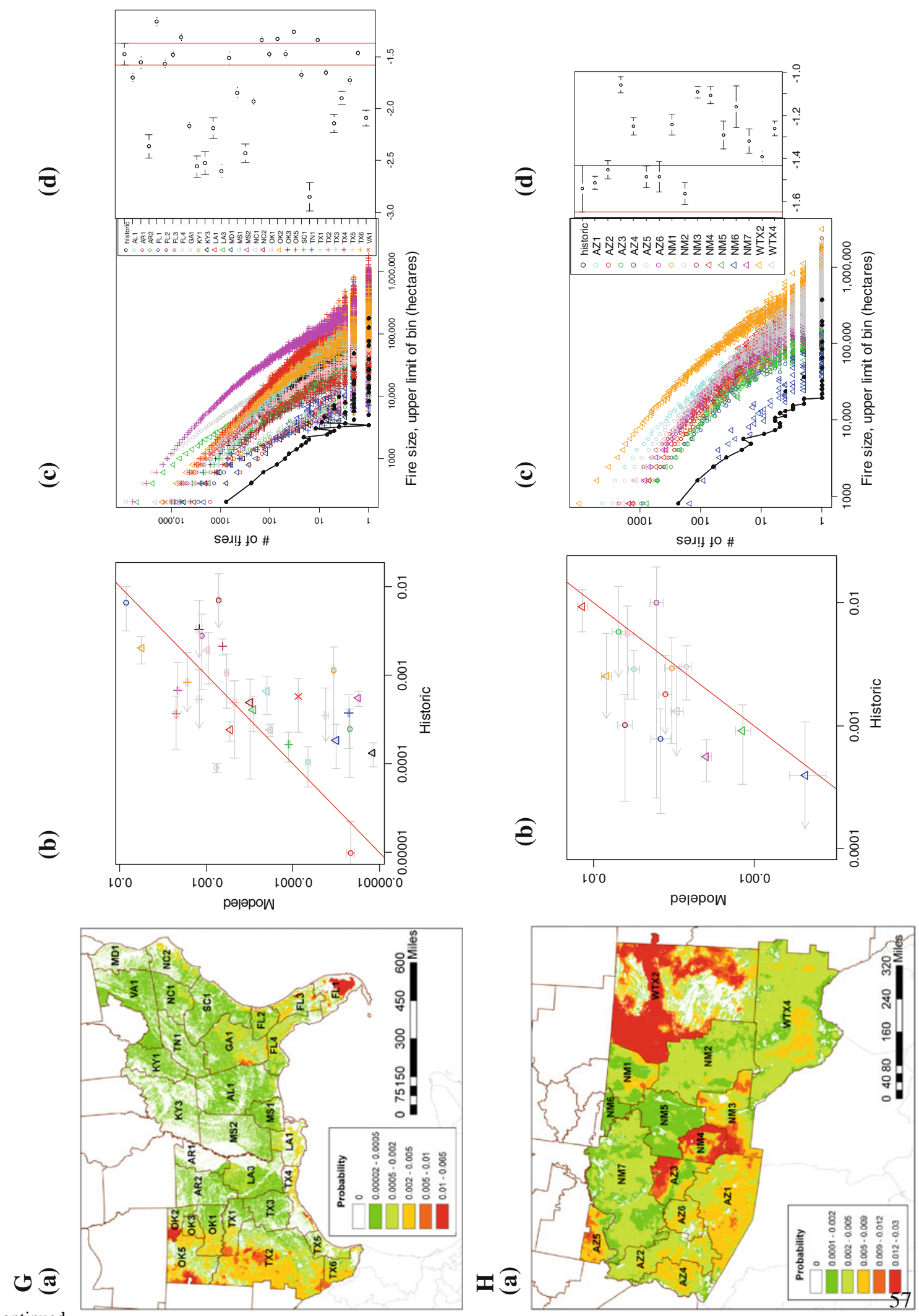

Fig. 8 continued 


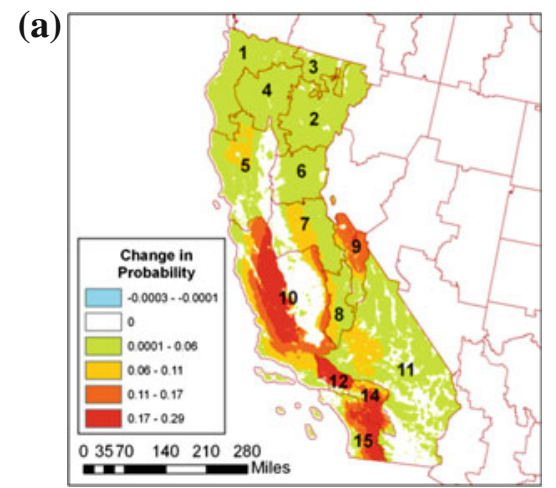

(b)
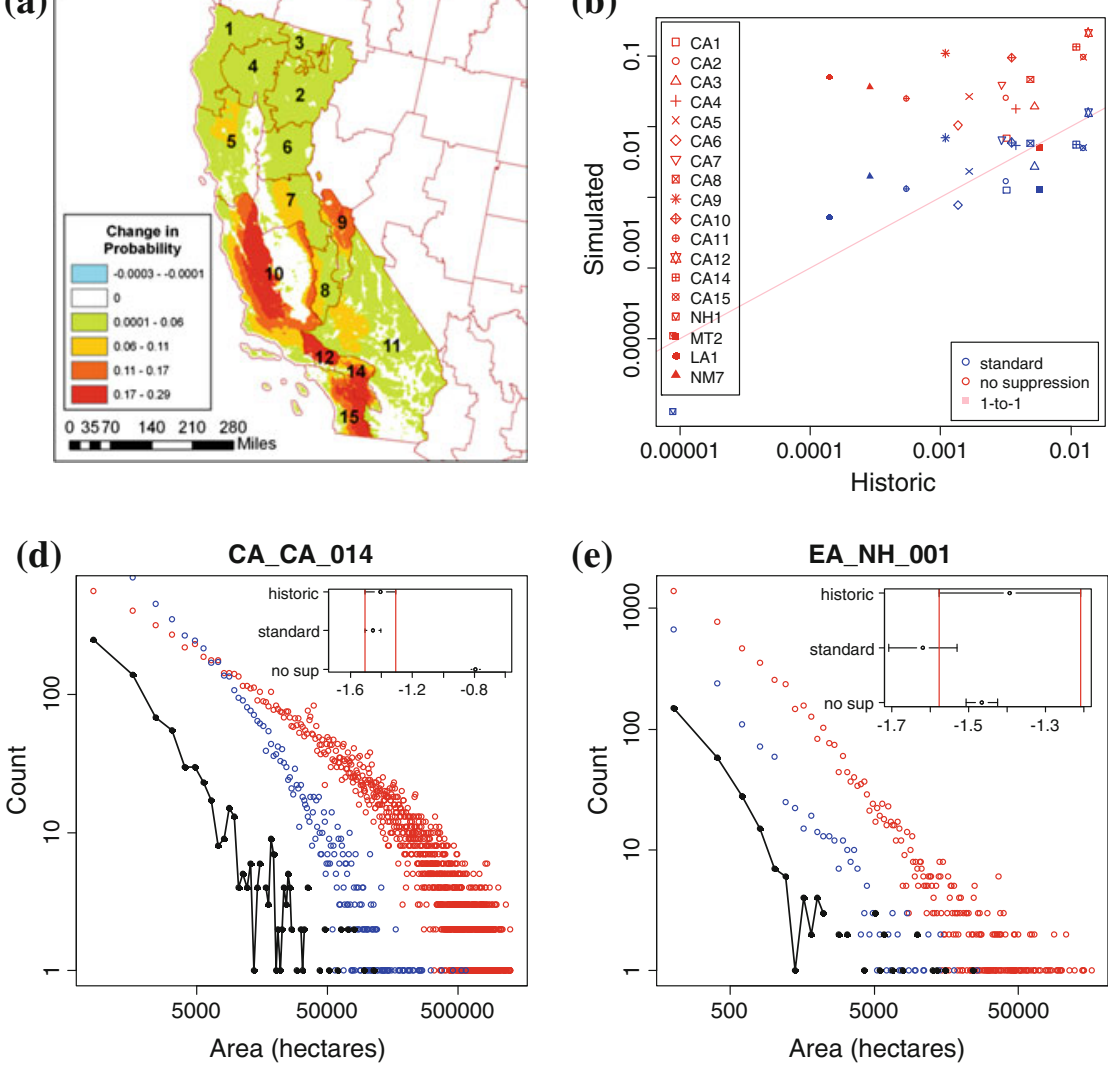

(e)

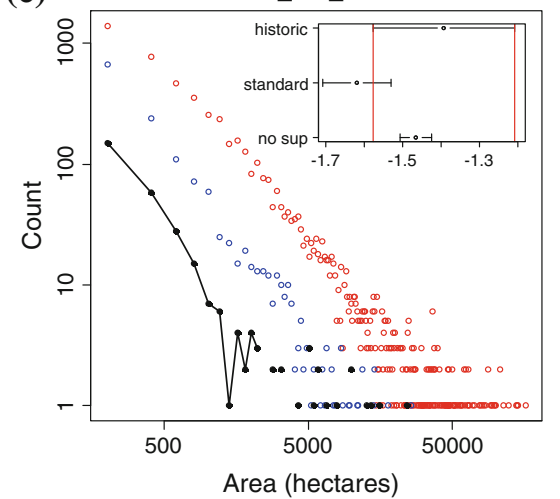

CA_CA_004
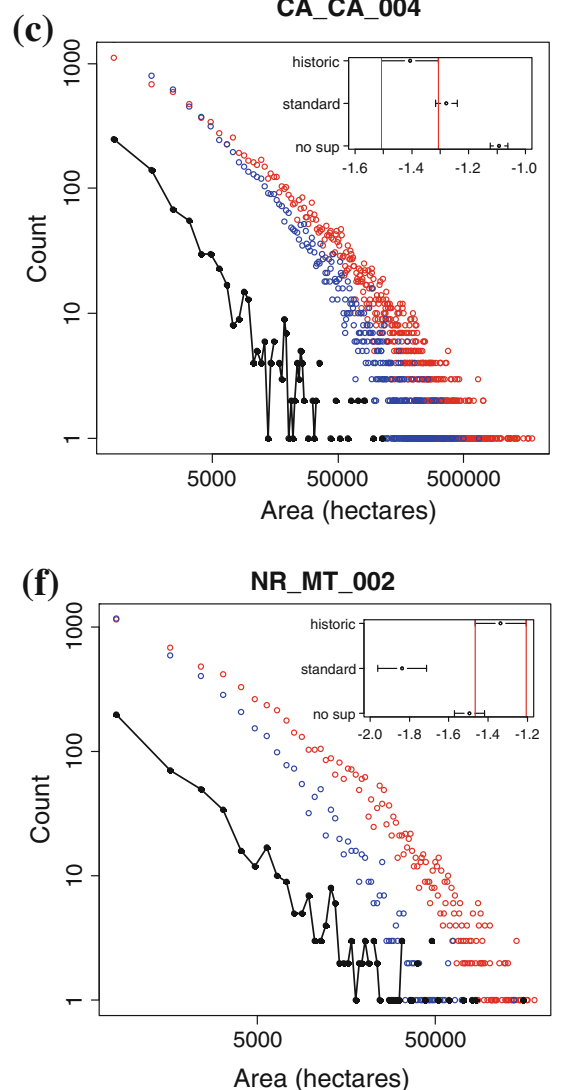

Fig. 9 Effects of the statistical fire containment model are demonstrated as a map of the net difference in modeled burn probabilities for California with and without large fire suppression (positive values signify higher burn probabilities without suppression), b historic vs. simulated average FPU burn probabilities for California and selected

The slopes of the simulated fire size distributions generally corresponded with the historical data and followed the trends suggested by Malamud et al. (2005), in which northeastern and southeastern areas of the U.S. have steeper slopes than the west. Clearly, however, the rarest of the simulated large fires are much larger than have yet been observed. There are several possible reasons for this, and they are difficult to disentangle. First, fire sizes depend on both the spatial continuity of fuels and the temporal opportunity for spread, and these two factors can jointly produce statistically rare conditions under which fires can grow beyond historical maxima. The very long $10,000-50,000$ year simulation period is expected to generate rare events that have not been seen in the relatively short historical period of record (Cui and Perera 2008) because large fires are very rare. Second, model simplifications to fuels and weather may also result in larger-thanexpected fire sizes. Clearly, by setting one weather condition per day we ignore the finer-scale weather variability known to affect fire behavior calculations (Anderson et al. 2007). Fuel variability at the sub- $270 \mathrm{~m}$ resolution is
FPUs, and c-e fire size distributions with and without implementing the suppression model compared to historic records for FPUs in California (c, d), New Hampshire (e) and Montana (f). Historic fire size distribution is shown in black, standard run in blue, and nosuppression run in red

likewise unrepresented in the simulation but roads, streams, urban development, or natural spatial heterogeneity in fuels and topography clearly introduces fire spread thresholds and censors large fire growth (Reed and McKelvey 2002; Ricotta et al. 1999; Yang et al. 2008). Third, our inability to fully account for the influences of suppression activities on fire growth could result in unrealistically large modeled fires. We only use a general statistical model for representing the very complicated effects of suppression on fire growth. Moritz et al. (2005) relied on a simple lower limit of spread rate for stopping fire movement in California chaparral and Braun et al. (2010) adjusted burn duration to improve fire size correspondence with historical data. Fire suppression activities can effect strong changes in fire growth depending on details not accounted for in our containment model, including tactics such as night-time operations and burnout from roads, rivers, and ridges, and the deployment of locally variable numbers and kinds of firefighting resources. These factors would be particularly influential on growth of fires in grass fuels or open shrub vegetation. Given these modeling 
(a)

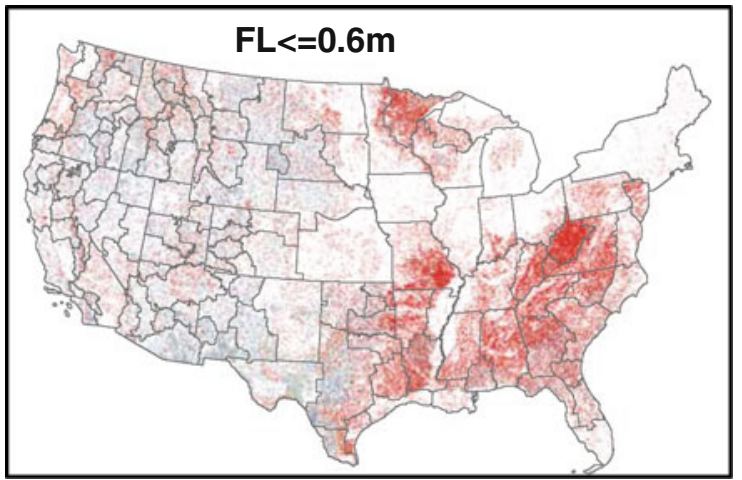

(c)

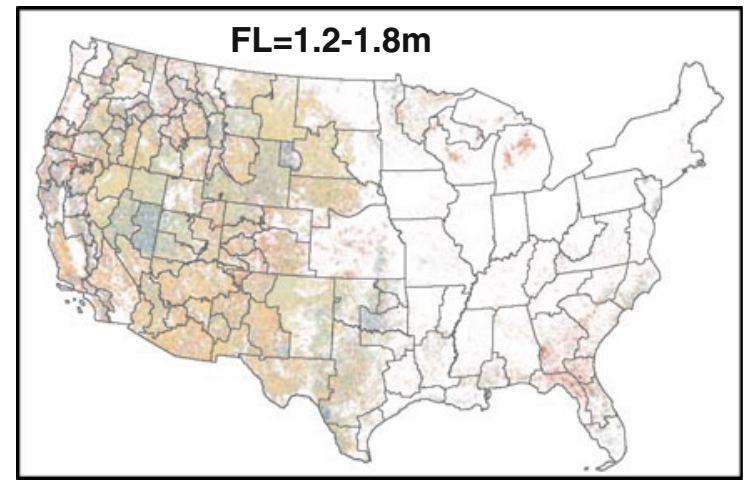

(e)

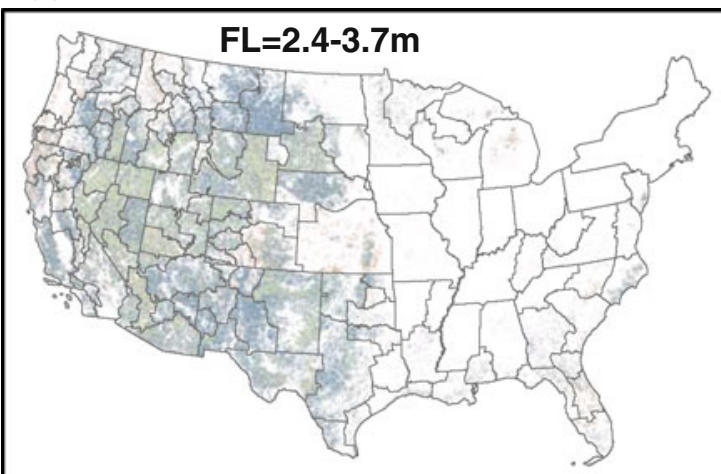

(b)

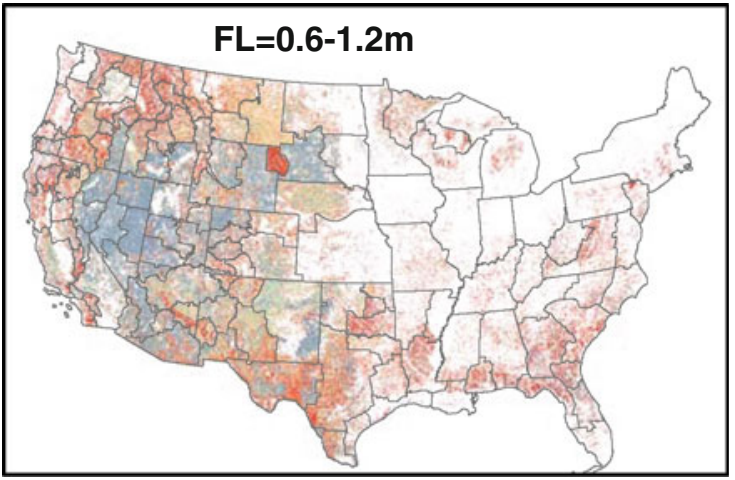

(d)

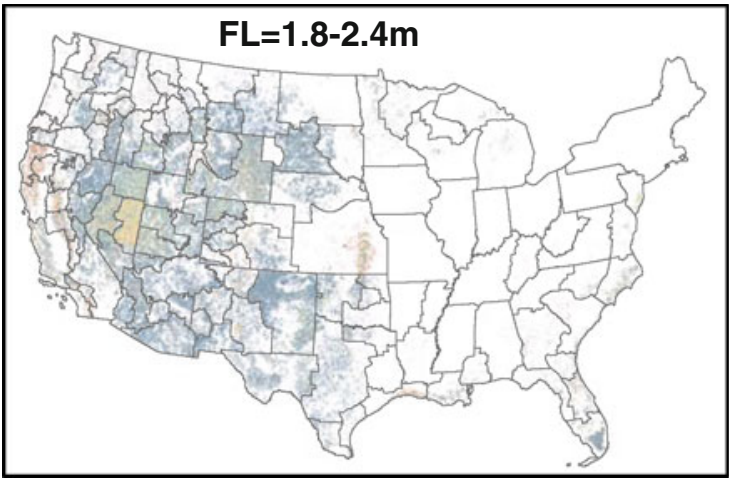

(f)

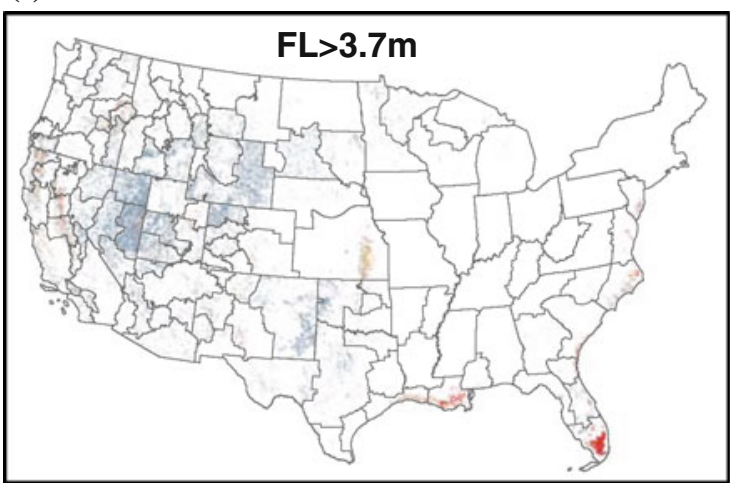

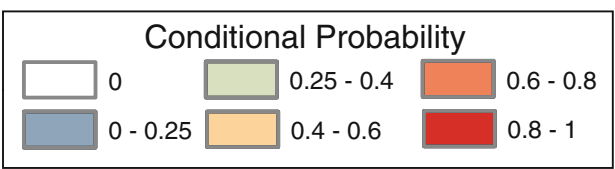

Fig. 10 Conditional burn probabilities for six flame length categories. a Under $2 \mathrm{ft}(0.6 \mathrm{~m}), \mathbf{b} 2-4 \mathrm{ft}(0.6-1.2 \mathrm{~m})$, c $4-6 \mathrm{ft}(1.2-1.8 \mathrm{~m})$, d 6-8 ft $(1.8-2.4 \mathrm{~m})$, e $8-12 \mathrm{ft}(2.4-3.7 \mathrm{~m})$, f Over $12 \mathrm{ft}(>3.7 \mathrm{~m})$

limitations, it may be useful to consider the introduction of some means of truncation on the fire size distributions that have been suggested by analysis of empirical data (Cui and Perera 2008; Cumming 2001; Moritz et al. 2005).

Despite an incomplete understanding of the effects of suppression on large fires, our modeling system demonstrates that suppression could be responsible for substantial reduction in both burn probabilities and fire sizes. Fire size distributions generated with the statistical containment model in place (Finney et al. 2009) have steeper slopes (indicating a greater proportion of small vs. large fires) than do those generated without containment. By censoring fire growth, suppression slows the accumulation of burned area, and proportionally reduces the frequency of larger fires in favor of smaller ones. The end result is an increase in the steepness of the modeled fire size distribution (Cui 
and Perera 2008) such that it more closely approximates the historical observations. The same finding was reported by Ward et al. (2001) who compared historical fire size distributions from areas in Ontario, Canada having intensive fire suppression activities and those in more remote areas having little suppression. Podur et al. (2009) and Braun et al. (2010) found reduced fire sizes and heightened fire frequencies in zones of intensive suppression. These effects on the fire size distribution also show up as reduced burn probabilities (or fire frequencies) due to reduced fire sizes. Fire sizes and burn probabilities can be quite closely related (Falk et al. 2007; Li et al. 1999). The high degree of correspondence between fire sizes and burn probabilities (simulated and historical) suggests that the current model formulation is capturing essential processes in ways that produce reasonable estimates of the probabilistic component of fire risk.

Of course, improvements in the FSim model structure and components can be made in many areas. For example, the assumption of uniform random large-fire start locations in this model and others (i.e., Moritz et al. 2005) probably is a source of error in fine-scale spatial patterns of burn probability and behavior (Massada et al. 2009). Our primary concern here is with fire-start locations resulting in large fires, which may not be a function of many factors related to the general ignition pattern, which includes vegetation type, management history, and spatial proximity to human activities (Cardille and Ventura 2001; Krawchuk et al. 2006; Krawchuk and Cumming 2009). Improvements to the model of large fire occurrence must consider management actions as a spatially variable ignition filterproducing a landscape characterized by different rates of detection and firefighting resource response time, which would allow fires to escape (become large) at spatially nonuniform frequencies (Arienti et al. 2006; Dickson et al. 2006; Syphard et al. 2008). Finally, a gridded ERC(G) time-series analysis could be used to better capture the variation in weather associated with major topographic features within FPUs which could then drive a spatially explicit model of large-fire ignition. Similar models have been demonstrated, with fire danger rating indices and other weather factors providing spatial predictions of fire occurrence (Preisler et al. 2004; Preisler and Westerling 2007).

\section{Conclusions}

Fire simulation was shown to be practical for use in continental-scale wildland fire risk assessments. The simulated burn probability and fire size distributions demonstrated reasonable fidelity to historical observations, suggesting that actuarial calculations of expected impacts to ecological and economic resources are possible. These methods also provide for the first time, the ability to evaluate land and fire management options for mitigating risk. Risk mitigation could entail local and landscape-level fuel management, which can affect burn probabilities and modify the behaviors of fire should it occur. Much work remains to be done by economists and natural resource specialists concerning the responses of highly valued resources to the physical behaviors of fire.

Acknowledgments The authors are indebted to Brent Timothy, Jim Hutton, Stu Bedoll, Tom Quigley, and Danny Lee for their hard work and dedication to developing and operating the simulation system. This effort was made possible by the financial and logistical support provided by Bill Breedlove, Barb Loving, and Donna Scholz on behalf of FPA.

\section{References}

Ager AA, Finney MA, Kerns BK, Maffei H (2007) Modeling wildfire risk to northern spotted owl (Strix occidentalis caurina) habitat in Central Oregon, USA. For Ecol Manag 246(1):45-56

Ager AA, Vaillant NM, Finney MA (2010) A comparison of landscape fuel treatment strategies to mitigate wildland fire risk in the urban interface and preserve old forest structure. For Ecol Manag 259(8):1556-1570

Albini FA (1979) Spot fire distance from burning trees-a predictive model. USDA Forest Service General Technical Report INT-56

Alexander ME (1982) Calculating and interpreting forest fire intensities. Can J Bot 60:349-357

Alvarado E, Sandberg DV, Pickford SG (1998) Modeling large forest fires as extreme events. Northwest Sci 72:66-75

Anderson DH, Catchpole EA, DeMestre NJ, Parkes T (1982) Modeling the spread of grass fires. J Aust Math Soc B 23:451-466

Anderson K, Reuter G, Flannigan MD (2007) Fire-growth modeling using meterological data with random and systematic perturbations. Int J Wild Fire 16:174-182

Andrews PL (1986) BEHAVE: fire behavior prediction and fuel modeling system- BURN subsystem, Part 1. USDA Forest Service General Technical Report INT-194

Andrews PL, Rothermel RC (1982) Charts for interpreting wildland fire characteristics. USDA Forest Service General Technical Report INT-131

Andrews PL, Loftsgaarden DO, Bradshaw LS (2003) Evaluation of fire danger rating indexes using logistic regression and percentile analysis. Int J Wild Fire 12:213-226

Arienti MA, Cumming SG, Boutin S (2006) Empirical models of forest fire initial attack success probabilities: the effects of fuels, anthropogenic linear features, fire weather, and management. Can J For Res 36:3155-3166

Bak P, Tang C, Weisenfeld K (1988) Self-organized criticality. Phys Rev A 38:364-374

Bak P, Chen K, Tang CJ (1990) A forest-fire model and some thoughts on turbulence. Phys Lett A 147:297-300

Ball GL, Guertin DP (1992) Improved fire growth modeling. Int J Wild Fire 2:47-54

Beverly JL, Wotton BM (2007) Modelling the probability of sustained flaming: predictive value of fire weather index components compared with observations of site weather and fuel moisture conditions. Int J Wild Fire 16:161-173 
Beverly JL, Herd EPK, Conner JCR (2009) Modeling fire susceptibility in west central Alberta, Canada. For Ecol Manag 258:1465-1478

Boer MM, Sadler RJ, Bradstock RA, Gill AM, Grierson PF (2008) Spatial scale invariance of southern Australian forest fires mirrors the scaling behavior of fire-driving weather events. Lansc Ecol 23:899-913

Box G, Jenkins G (1976) Time series analysis: forecasting and control, 2nd edn. Holden Day, San Francisco

Bradshaw LS, Deeming JE, Burgan RE, Cohen JD (1984) The 1978 National Fire Danger Rating system: technical documentation. USDA Forest Service General Technical Report INT-169

Bradstock RA, Cohn JS, Gill AM, Bedward M, Lucas C (2009) Prediction of the probability of large fires in the Sydney region of south-eastern Australia using fire weather. Int J Wild Fire 18:932-943

Bratten FW, Davis JB, Flatman GT, Keith JW, Rapp SR, Storey TG (1981) FOCUS: a fire management planning system-final report. U.S. Forest Service, Pacific Southwest Forest and Range Experiment Station GTR-PSW-49

Braun, WJ, Jones, BL, Lee JSW, Woodford DG, Wotton BM (2010) Forest fire risk assessment: an illustrative example from Ontario, Canada. J Prob Stat 2010, Article 823018

Brillinger DR (2003) Three environmental probabilistic risk problems. Stat Sci 18:412-421

Brillinger DR, Preisler HK, Benoit JW (2006) Probabilistic risk assessment for wildfires. Environmetrics 17:623-633

Brown TJ, Hall BL, Mohrle CR, Reinbold HJ (2002) Coarse assessment of federal wildland fire occurrence data. Report for the National Fire Coordinating Group, CEFA 02-04, Desert Research Institute Program for Climate, Ecosystem, and Fire Applications

Byram GM (1959) Combustion of forest fuels. In: Davis KP (ed) Forest fire: control and use. McGraw-Hill, New York

Calkin DE, Gebert KM, Jones G, Neilson RP (2005) Forest service large fire area burned and suppression expenditure trends 1970-2002. J For 103(4):179-183

Calkin DE, Ager AA, Gilbertson-Day J, Scott JH, Finney MA, Schrader-Patton C, Quigley TM, Strittholt JR, Kaiden JD (2010) Wildfire risk and hazard: procedures for the first approximation. U.S. Forest Service, Rocky Mountain Research Station RMRSGTR-235

Cardille JA, Ventura SJ (2001) Occurrence of wildfire in the northern Great Lakes Region: effects of land cover and landownership assessed at multiple scales. Intl $\mathrm{J}$ Wildl Fire 10(2):145-154

Catchpole EA, DeMestre NJ, Gill AM (1982) Intensity of fire at its perimeter. Aust For Res 12:47-54

Catchpole EA, Alexander ME, Gill AM (1992) Elliptical-fire perimeter- and area-intensity distributions. Can J For Res 22:968-972

Chandler CC, Storey TG, Tangren CD (1963) Prediction of fire spread following nuclear explosions. U.S. Forest Service Pacific Southwest Forest and Range Experiment Station Research Paper PSW-5

Collins BM, Kelly M, van Wagtendonk JW, Stephens SL (2007) Spatial patterns of large natural fires in Sierra Nevada wilderness areas. Lansc Ecol 22:545-557

Collins BM, Stephens SL, Moghaddas JJ, Battles J (2010) Challenges and approaches in planning fuel treatments across fire-excluded forested landscapes. J For 108(1):24-31

Cui W, Perera AH (2008) What do we know about forest fire size distribution, and why is this knowledge useful for forest management? Int J Wild Fire 17:234-244

Cumming SG (2001) A parametric model of the fire-size distribution. Can J For Res 31:1297-1303
Deeming JE, Burgan RE, Cohen JD (1977) The National Fire Danger Rating System, 1978. U.S. Forest Service General Technical Report INT-39

Dickson BG, Prather JW, Yaguang X, Hampton HM, Aumack EN, Sisk TD (2006) Mapping the probability of large fire occurrence in northern Arizona, USA. Landscape Ecol 21:747-761

Efron B, Tibshirani R (1986) Bootstrap methods for standard errors, confidence intervals, and other measures of statistical accuracy. Stat Sci 1(1):54-77

Fairbrother A, Turnley JG (2005) Predicting risks of uncharacteristic wildfires: application of the risk assessment process. For Ecol Manag 211:28-35

Falk DA, Miller C, McKenzie D, Black AE (2007) Cross scale analysis of fire regimes. Ecosyst 10:809-823

Fernandes PM, Botelho H, Rego F, Loureiro C (2008) Using fuel and weather variables to predict the sustainability of surface fire spread in maritime pine stands. Can J For Res 38:190-201

Finney MA (1998) FARSITE: fire area simulator-model development and evaluation. U.S. Forest Service Research Paper RMRS-RP-4

Finney MA (2002) Fire growth using minimum travel time methods. Can J For Res 32(8):1420-1424

Finney MA (2005) The challenge of quantitative risk assessment for wildland fire. For Ecol Manag 211:97-108

Finney MA (2006) An overview of FlamMap fire modeling capabilities. U.S. Forest Service General Technical Report RMRS-P-41

Finney MA, McHugh CW, Grenfell IC (2005) Stand- and landscapelevel effects of prescribed burning on two Arizona wildfires. Can J For Res 35:1714-1722

Finney MA, Grenfell IC, McHugh CW (2009) Modeling large fire containment using generalized linear mixed model analysis. For Sci 55(3):249-255

Flowers PJ, Hunter TP, Mills TJ (1983) Design of a model to simulate large-fire suppression effectiveness. In: Proceedings of the 7th conference on fire and forest meteorology, Boston. American Meteorological Society, Boston, pp 168-173

Fosberg MA, Deeming JE (1971) Derivation of the 1- and 10-hour timelag fuel moisture calculations for fire danger rating. U.S. Forest Service Research Note RM-207

Gebert KM, Calkin DE, Yoder J (2007) Estimating suppression expenditures for individual large wildland fires. West J Appl For 3:188-196

Gonzalez JR, del Barrio G, Duguy B (2007) Assessing functional landscape connectivity for disturbance propagation on regional scales-a cost-surface model approach applied to surface fire spread. Ecol Model 211:121-141

Graham RT, Jain TB, Loseke M (2009) Fuel treatments, fire suppression, and their interactions with wildfire and its effects: the Warm Lake experience during the Cascade Complex of wildfires in central Idaho, 2007. U.S. Forest Service General Technical Report RMRS-GTR-229

Heinselman ML (1973) Fire in the virgin forests of the Boundary Waters Canoe Area, Minnesota. Quat Res 3:329-382

Hood S, McHugh CW, Ryan KC, Reinhardt ED, Smith SL (2007) Evaluation of a post-fire tree mortality model for western USA conifers. Int J Wild Fire 16:679-689

Jones SD, Garvey MF, Hunter GJ (2004) Where's the fire? Quantifying uncertainty in a wildfire threat model. Int J Wild Fire 13:17-25

Jordan GJ, Fortin MJ, Lertzman KP (2008) Spatial pattern and persistence of historical fire boundaries in southern interior British Columbia. Environ Ecol Stat 15:523-535

Kalvova J, Sobisek B (1981) Periodicity in time series of wind direction data. Stud Geophys Geod 25:275-283

Kellogg LB, McKenzie D, Peterson DL, Hessl AE (2008) Spatial models for inferring topographic controls on historical low- 
severity fire in the eastern Cascade Range of Washington, USA. Lansc Ecol 23:227-240

Kerby JD, Fuhlendorf SD, Engle DM (2007) Landscape heterogeneity and fire behavior: scale-dependent feedback between fire and grazing processes. Lansc Ecol 22:507-516

Kerns BK, Ager AA (2007) Risk assessment for biodiversity conservation planning in Pacific Northwest forests. For Ecol Manag 246:38-44

King KJ, Bradstock RA, Cary GJ, Chapman J, Marsden-Smedley JB (2008) The relative importance of fine-scale fuel mosaics on reducing fire risk in south-west Tasmania, Australia. Int J Wild Fire 17:421-430

Krawchuk MA, Cumming SG (2009) Disturbance history affects lightning fire initiation in the mixedwood boreal forest: observations and simulations. For Ecol Manag 257(7):1613-1622

Krawchuk MA, Cumming SG, Flannigan MD, Wein RW (2006) Biotic and abiotic regulation of lightning fire initiation in the mixedwood boreal forest. Ecology 87:458-468

Leonard S (2009) Predicting sustained fire spread in Tasmanian native grasslands. Environ Manag 44:430-440

Li C, Corns IGW, Yang RC (1999) Fire frequency and size distributions under natural conditions: a new hypothesis. Lansc Ecol 14:533-542

Liang J, Calkin DE, Gebert KM, Venn TJ, Silverstein RP (2008) Factors influencing large fire expenditures. Int $\mathrm{J}$ Wild Fire 17:650-659

Littell JS, McKenzie D, Peterson DL, Westerling AL (2009) Climate and wildfire area burned in western U.S. ecoprovinces, 1916-2003. Ecol Appl 19(4):1003-1021

Malamud BD, Morein G, Turcotte DL (1998) Forest fires: an example of self-organized critical behavior. Science 281:1840-1842

Malamud BD, Millington JDA, Perry GLW (2005) Characterizing wildfire regimes in the United States. Proc Natl Acad Sci 102(13):4694-4699

Martell DL, Sun H (2008) The impact of fire suppression, vegetation, and weather on the area burned by lightning-caused forest fires in Ontario. Can J For Res 38:1547-1563

Martell DL, Otukul S, Stocks BJ (1987) A logistic model for predicting daily people-caused forest fire occurence in Ontario. Can J For Res 17:1555-1563

Massada AB, Radeloff VC, Stewart SI, Hawbaker TJ (2009) Wildfire risk in the wildland -urban interface: a simulation study in northwestern Wisconsin. For Ecol Mgt 258:1990-1999

Millington JDA, Perry GLW, Malamud BD (2006) Models, data and mechanisms: quantifying wildfire regimes. In: Cello G, Malamud BD (eds) Fractal analysis for natural hazards. Geological Society of London, London Special Publications 261, pp 155-167

Moritz MA, Morais ME, Summerell LA, Carlson JM, Doyle J (2005) Wildfires, complexity, and highly optimized tolerance. Proc Natl Acad Sci 102(50):17912-17917

Parisien M-A, Moritz MA (2009) Environmental controls on the distribution of wildfire at multiple spatial scales. Ecol Monogr 79(1):127-154

Parisien M-A, Kafka V, Hirsch KG, Todd JB, Lavoie SG, Maczek PD (2005) Mapping wildfire susceptibility with the BURN-P3 simulation model. Natural Resources Canada, Canadian Forest Service, Northern Forestry Center, Edmonton. Northern Forestry Centre Information Report NOR-X-405

Parisien M-A, Junor DR, Kafka VG (2007) Comparing landscape-based decision rules for placement of fuel treatments in the boreal mixedwood of western Canada. Int J Wild Fire 16:664-672

Peterson DL, Ryan KC (1986) Modeling postfire conifer mortality for long-range planning. Environ Manag 10(6):797-808

Peterson SH, Morais ME, Carlson JM, Dennison PE, Roberts DA, Moritz MA, Weise DR (2009) Using HFire for spatial modeling of fire in shrublands. U.S. Forest Service Pacific Southwest Research Station PSW-RP-259

Podur JJ, Martell DL (2007) A simulation model of the growth and suppression of large forest fires in Ontario. Int $\mathrm{J}$ Wild Fire 16:285-294

Podur JJ, Martell DL, Sanford D (2009) A compound Poisson model for the annual area burned by forest fires in the province of Ontario. Environmetrics 21(5):457-469

Preisler HK, Westerling AL (2007) Statistical model for forecasting monthly large wildfire events in western United States. J Appl Meteorol 46:1020-1030

Preisler HK, Brillinger DR, Burgan RE, Benoit JW (2004) Probability based models of estimation of wildfire risk. Int J Wild Fire 13:133-142

Preisler HK, Burgan RE, Eidenshink JC, Klaver JM, Klaver RW (2009) Forecasting distributions of large federal-lands fires utilizing satellite and gridded weather information. Intl J Wildl Fire 18:508-516

Reed WJ, McKelvey KS (2002) Power-law behaviour and parametric models for the size-distribution of forest fires. Ecol Model 150:239-254

Richards GD (1995) A general mathematical framework for modeling two-dimensional wildland fire spread. Int J Wild Fire 5(2):63-72

Ricotta C, Avena G, Marchetti M (1999) The flaming sandpile: selforganized criticality and wildfires. Ecol Model 119:73-77

Rollins MG, Swetnam TW, Morgan P (2001) Evaluating a century of fire patterns in two Rocky Mountain wilderness areas using digital fire atlases. Can J For Res 31:2107-2123

Rothermel RC (1972) A mathematical model for predicting fire spread in wildland fuels. U.S. Forest Service Research Paper INT-115

Rothermel RC (1991) Predicting behavior and size of crown fires in the northern Rocky Mountains. U.S. Forest Service Research Paper INT-438

Salvador R, Pinol J, Tarantola S, Pla E (2001) Global sensitivity analysis and scale effects of a fire propagation model used over Mediterranean shrublands. Ecolo Model 136:175-189

Schmidt K, Menakis JP, Hardy CC, Hann WJ, Bunnell DL (2002) Development of coarse-scale spatial data for wildland fire and fuel management. U.S. Forest Service, Rocky Mountain Research Station GTR-RMRS-87

Schmidt DA, Taylor AH, Skinner CN (2008) The influence of fuels treatment and landscape arrangement on simulated fire behavior, Southern Cascade range, California. For Ecol Manag 255:3170-3184

Schroeder MJ, Buck CC (1970) Fire weather: a guide for application of meteorological information to forest fire control operations. U.S. Department of Agriculture Agricultural Handbook 360

Scott JH (2006) An analytical framework for quantifying wildland fire risk and fuel treatment benefit. In: Andrews PL, Butler BW (eds) Fuel management-how to measure success: conference proceedings, 28-30 Mar 2006, Portland, OR. U.S. Forest Service GTR-RMRS-P-41, pp 169-184

Scott JH, Burgan RE (2005) Standard fire behavior fuel models: a comprehensive set for use with Rothermel's surface fire spread model. USDA Forest Service, Rocky Mountain Research Station, General Technical Report RMRS-GTR-153

Sen PK (1968) Estimates of the regression coefficient based on Kendall's Tau. J Am Stat Assoc 63:1379-1389

Stephens SL, Martin RE, Clinton NE (2007) Prehistoric fire area and emissions from California's forests, woodlands, shrublands, and grasslands. For Ecol Manag 251:205-216

Stephens SL, Moghaddas JJ, Edminster C, Fiedler CE, Haase S, Harrington M, Keely JE, Knapp EE, McIver JD, Metlen K, Skinner CN, Youngblood A (2009) Fire treatment effects on 
vegetation structure, fuels, and potential fire severity in western U.S forests. Ecol Appl 19(2):305-320

Strauss D, Bednar L, Mees R (1989) Do one percent of forest fires cause ninety-nine percent of the damage? For Sci 35(2):319-328

Suffling R, Grant A, Feick R (2008) Modeling prescribed burns to serve as regional firebreaks to allow wildfire activity in protected areas. For Ecol Manag 256:1815-1824

Syphard AD, Radeloff VC, Keuler NS, Taylor RS, Hawbaker TJ, Stewart SI, Clayton MK (2008) Predicting spatial patterns of fire on a southern California landscape. Intl $\mathrm{J}$ Wildfire Fire 17:602-613

Tebbens SF, Burroughs SM (2005) Forest fire burn areas in Western Canada modeled as self-similar criticality. Phys D 211:221-234

Thompson MP, Calkin DE, Finney MA, Ager AA, Gilbertson-Day JW (2011) Integrated national-scale assessment of wildfire risk to human and ecological values. Stoch Environ Res Risk Assess. doi:10.1007/s00477-011-0461-0

Van Wagner CE (1977) Conditions for the start and spread of crown fire. Can J For Res 7:23-34

van Wagtendonk JW (1995) Large fires in wilderness areas. In Proceedings: symposium on fire in wilderness and park management. 30 Mar-1 Apr 1993, Missoula. General Technical Report INT-GTR-320. (JK Brown, RW Mutch, CW Spoon, RH Wakimoto, Tech. Coords), USDA Forest Service, Intermountain Research Station Ogden, UT, pp 113-116

Viedma O, Angeler DG, Moreno JM (2009) Landscape structural features control fire size in a Mediterranean forested area of central Spain. Int J Wild Fire 18:575-583

Ward PC, Tithecott AG, Wotton BM (2001) Reply_a re-examination of the effects of fire suppression in the boreal forest. Can J For Res 31:1467-1480

Wimberly MC, Cochrane AD, Baer AD, Pabst K (2009) Assessing fuel treatment effectiveness using satellite imagery and spatial statistics. Ecol Appl 19(6):1377-1384

Yang J, He HS, Shifley SR (2008) Spatial controls of occurrence and spread of wildfires in the Missouri Ozark Highlands. Ecol Appl 18(5):1212-1225

Zachariasson J, Zeller K, Nikolov N, McClelland T (2003) A review of the Forest Service Remote Automated Weather Station (RAWS) Network. USDA Forest Service, Rocky Mountain Research Station, General Technical Report RMRS-GTR-119 